\title{
Eastern Enlargement of the EU: Jobs, Investment and Welfare in Present Member Countries
}

\author{
by \\ BEN J. HEIJDRA \\ University of Groningen and OCFEB \\ Christian Keuschnigg \\ University of St. Gallen (IFF-HSG), CEPR and CESifo \\ WiHelm KoHLER \\ Johannes Kepler University Linz
}

February 2002

\begin{abstract}
Eastern enlargement of the EU promises gains, but also imposes fiscal costs on incumbent countries. A sensitive issue concerns immigration, jobs and wages. We address these issues in a general equilibrium framework, both analytically and through numerical simulations. Analytical results identify capital accumulation as a prime transmission channel. Using a dynamic CGE model with search unemployment of high- and low-skilled labor, we simulate the effects of enlargement on Germany finding small effects from trade, but more pronounced labor market effects from migration. Based on German model elasticities, we approximate expected benefits and costs for other member countries as well.
\end{abstract}

Keywords: EU enlargement, economic integration, economic growth, capital accumulation, search unemployment, computable general equilibrium analysis.

JEL Codes: C68, F13, F15

Heijdra: Dep. of Economics, P.O.Box 800, NL-9700 AV Groningen, The Netherlands, phone:+31-503637303/6664, fax:-7207, e-mail: b.j.heijdra@eco.rug.nl

Keuschnigg (corresponding author): IFF-HSG, Varnbuelstrasse 19, CH-9000 St.Gallen, Switzerland, phone:+41-71-224-2520, fax:-2670, e-mail: Christian.Keuschnigg@unisg.ch, http://www.iff.unisg.ch

Kohler: Dep. of Economics, Altenberger Strasse 69, A-4040 Linz-Auhof, Austria, phone:+43-732-24688239, fax:-8238, e-mail: Wilhelm.Kohler@jk.uni-linz.ac.at.

We gratefully acknowledge financial support received from the Austrian Science Fund (FWF) under grant no. P14702. The paper was presented at the University of Copenhagen (EPRU), the Austrian Economic Association meeting, the CEPR workshop ERWIT 2000, and the CESifo workshop 2001 on Managing EU Enlargement. We appreciate useful comments by A.L. Bovenberg, M. Keuschnigg, P.B. Sørensen, by other seminar participants and, in particular, by our discussant A. Belke. 


\section{Introduction}

Based on the Maastricht treaty of 1992, the European Council has issued a firm commitment towards an eastern enlargement of the European Union at the Copenhagen summit of 1993. Within a short period of time it was faced with 10 membership applications from central and eastern European countries (CEECs). The Luxembourg summit of December 1997 marks the beginning of formal negotiations with a first group of five CEECs. Two years later, following the Helsinki summit of 1999, negotiations were extended to the remaining applicant countries from CEE, plus Malta and Cyprus. ${ }^{1}$ The prime purpose of these negotiations is to assure a complete adoption of all existing Union legislation (acquis communautaire) by future member countries. But taking in as many as 12 new members requires significant change also on the part of the Union itself. In December 2000, at their summit in Nice, the EU15 heads of state have agreed to enact an institutional reform aimed at a smooth and efficient operation of an EU27. Continuous progress notwithstanding, however, eastern enlargement continues to be a hotly debated policy issue in virtually all present member countries. While the process appears to be driven by political forces, economic considerations generate formidable stumbling blocks. Much of the early discussion in EU15 countries has focused on the costs of enlargement. More recently, as the negotiation agenda has reached the implications of the single market for labor migration, labor market concerns in several incumbent countries give rise to additional strain in the enlargement process.

Economists were quick to point out that integration of CEE goods and factor markets gives rise to economic benefits also to EU15 countries which tend to offset the burden of increased transfers to new member countries. But empirical analysis has revealed that the expected gains are relatively small in size. Baldwin et al. (1997) have argued that the benefits of enlargement are of only minor importance for the EU15 as a whole, but mainly accrue to the Eastern accession countries. This seems to justify a preoccupation with the fiscal burden, although we have shown in a series of papers that in the case of Austria and Germany the integration gains are sufficiently large to overcompensate the fiscal burden [see Keuschnigg \& Kohler (2002), Kohler \& Keuschnigg (2001), and Keuschnigg et al. 2001)].

Two important issues, however, remain for further scrutiny. First, in assuming continuous labor market clearing, these early studies were probably too sanguine about employment. Given

\footnotetext{
${ }^{1}$ Throughout this paper, the term CEECs refers to 10 countries presently negotiating for EU membership. The CEEC5s comprise the countries which have started negotiations already in 1998, often referred to as the "Luxembourg group", i.e. Czech Republic, Estonia, Hungary, Poland and Slovenia. The CEEC10s additionally include the "Helsinki-group", i.e. Bulgaria, Latvia, Lithuania, Romania, and the Slovak Republic.
} 
widespread unemployment in Europe, the analysis of enlargement should appropriately include potential effects on unemployment by a more realistic treatment of labor markets. The second issue relates to differences among EU15 countries. Obviously, the results obtained for Germany and Austria cannot be assumed to hold for other countries as well. In countries at the western and southern periphery, east-west market integration seems less important than the fiscal implications of enlargement. Empirical studies should thus address more closely the likely effects on unemployment and wages of skilled and unskilled labor, and they should also compare the differential effects on countries located near the eastern border and on non-border countries like Spain or the UK.

This paper takes up both of these issues, making a theoretical as well as an empirical contribution. To address unemployment, we propose a search theoretic framework of job creation and destruction which we combine with capital accumulation as a prime transmission mechanism for integration effects. We first show analytically how enlargement is expected to affect employment. Reflecting the general concern about unemployment effects of demographic change and population dynamics, we merge our search theoretic approach to the labor market with an overlapping generations model of household behavior. This turns out to be of particular relevance for migration. Specifically, we shall demonstrate that immigration has important transitional effects on employment, depending on the age structure of migrants.

Turning to the empirical side, we implement a multi-sector dynamic general equilibrium model with exogenous trend growth of labor productivity. Calibration and numerical solutions allow us to determine enlargement effects for the German economy. The model in this paper extends the basic model of Keuschnigg et al. (2001) by incorporating search unemployment, separately for high- and low-skilled workers [see Heijdra and Keuschnigg (2000) for a more detailed presentation]. This allows for a much richer treatment of enlargement effects. Among the effects considered are capital accumulation, unemployment, the government budget, income distribution, and overall welfare. The model allows to address an enlargement scenario focusing on commodity market integration, budgetary effects and, notably, immigration from applicant countries. Finally, we extend the results obtained for the German case to all other EU15 countries, relying on a method that we have developed in Keuschnigg \& Kohler (1996b).

The paper is structured as follows. Section 2 offers a general description of the eastern enlargement scenario, as it is perceived by present member countries. Section 3 introduces the core elements of the model and develops key intuitive insights on how immigration and market integration may affect investment, unemployment and welfare in an open economy. To this end, the appendix formally derives some analytical results. Section 4 defines the specific enlargement scenario in quantitative terms and discusses simulation results from our CGE model for Germany. Based on German model elasticities, section 5 approximates benefits and costs of 
enlargement for other EU15 countries. Section 6 closes the paper with a summary and some suggestions for future research.

\section{Eastern Enlargement of the EU}

While similar in terms of its quantitative significance to the southern enlargement (Greece, Spain and Portugal) in the 1980s, the upcoming eastern enlargement forms an unprecedented challenge in five distinct ways. First, it involves countries which are still in transition to market economies. This is reflected by special conditions for entry (stable democracies, competitive market economies, adoption of the acquis communautaire), that have been made explicit at the outset in the Copenhagen summit of 1993. Second, the income gaps to incumbent countries, even after 10 years of transition, are still enormous. Enlargement is therefore likely to generate severe strains, given the objective of regional convergence and coherence, which is a cornerstone of the Union and draws 40 percent of its expenditure. Third, expected migration flows are larger than for the southern enlargement, unless restricted by policy. Overall, eastern European countries are home to a well educated labor force. The income gaps do not reflect equal differences in personal skills and human capital. In addition, geographic proximity and cultural ties make for low "natural" migration barriers. Hence, some EU15 countries expect large inflows of eastern European labor which might put their labor markets under severe pressure. A fourth point relates to agriculture. The farming sector in some candidate countries is very large, and productivity is often much below the EU15 level, more so than with southern enlargement of the 1980s. ${ }^{2}$ This has severe implications for the Common Agricultural Policy which aims to support farm income and which draws another 40 percent of the EU budget. Finally, the number of candidates is a problem of its own. EU institutions and rules of decision making have been designed for a Union of 9 to 12 countries and are inappropriate for a 25-country Union. In the Nice summit of 2000, despite much controversy over various specific proposals, the European Council has succeeded to set the stage for a reform aimed at institutional structures which are more appropriate for the enlarged Union.

For comparison, figure 1 takes a "snapshot-view" of previous and upcoming enlargements. It looks at various groups of countries forming the European Union at different stages of its history, but always looking at 1995 data. Although the Helsinki summit of 1999 has started an "open race" for all 10 applicant CEECs, we separate the Luxembourg group of CEEC5-countries from the rest. In addition to population, the figure looks at GDP-per-capita (current exchange

\footnotetext{
${ }^{2}$ This is particularly true for Poland where the agricultural share of employment is about 25 percent and which at the same time is by far the largest candidate country; see European Commission (1997) and ECOFIN (2001).
} 
rates and $\mathrm{PPP}$ ), as well as the agricultural shares in employment and value-added. The figure shows that, as it grew in size, the Union has almost steadily become a less wealthy and more agricultural Union. Moreover, the income-gap involved in the eastern enlargement is clearly enormous, compared with previous enlargements. On the other hand, the incremental effect on the share of agriculture is not without precedent. Notice, however, that the effect is larger in terms of employment share than in terms of the value-added share, reflecting a productivity difference. ${ }^{3}$

Enlargement will affect present member countries in at least three distinct ways. They will find themselves in larger integrated markets for goods and factors, they will have to shoulder higher net contributions to the Union, and they will face a new institutional environment for decision making and administration within the Union. In each of these dimensions, there are significant differences among member countries.

Due to the Europe Agreements of the mid 1990s, non-agricultural trade between the EU15 and the CEECs is largely tariff-free. Enlargement will do away with all remaining tariff-barriers, and it will extend the Customs Union as well as the EU Single Market (SM) to new members, which will further enhance trade and factor movements. As always, this entails a mixture of efficiency gains and painful adjustment. History and geography put present member countries in rather different positions with respect to these "gains and pains" from integrating eastern European markets. Figure 2 highlights some of this variance by looking at the importance of merchandize trade with the CEEC10-candidates for each of the EU15 countries. To allow for a convenient comparison, we express all magnitudes relative to the corresponding value for the EU15 as a whole, which we set equal to 100. Trade shares are in percent of GDP which gives a more valid indicator for integration gains than the shares of trade with CEECs in overall trade; see Kohler (2000a). Despite the significant increase in east-west trade during the 1990s, trade with CEECs is still of relatively minor importance for the total EU: 1997 exports to CEEC10s were 1.08 percent of GDP $(=100)$, the corresponding share for imports is a mere 0.79 percent $(=100)$. However, the cross-country variation is substantial. Thus, the export share for Portugal is less than a fifth of the EU-wide share, while the Austrian share is well over 3 times the EU15value. On the import side, the variation is similar, ranging from 0.16 percent for Ireland to 2.71 percent for Austria which is almost 4 times the EU-value. The difference between EU15countries in terms of these trade shares seems to persist as the level of east-west trade increases

\footnotetext{
${ }^{3}$ The productivity difference is probably larger than may appear from figure 1. ECOFIN (2001) emphasizes that both labor productivity and output per unit of land are significantly lower in the present applicant countries, compared to EU15, than they were in Greece, Spain and Portugal, compared to EC9 prior to southern enlargement. For a more detailed comparative account of the southern enlargement, see also European Integration Consortium (EIC), 2001, Part B: Strategic Report.
} 
through time [see Kohler (2000b)].

For two reasons, it matters a lot whether a country is more heavily exposed on the export or the import side. First, removal of formal barriers starts from a higher level for EU15 exports into the CEECs than for its imports. Thus, pre-EA MFN tariffs on CEECs' imports into the EU15 amounted to about 7 percent on average for all goods. In contrast, EU15 exports faced average tariffs in some CEECs well above 10 percent, Poland leading with 15 percent [see European Integration Consortium (2001)]. The second point relates to trade costs which also restricts access to the SM, as opposed to pure distortions (tariffs and quantitative restrictions). Because an extension of the SM involves a savings in real resources, the expected gains are much larger than from removing pure distortions. ${ }^{4}$ A priori, the gains are more significant on the import than on the export side. Under perfect competition, there is a direct gain from cheaper imports, whereas on the export side the gain comes about only indirectly through a terms-of-trade effect [see Kohler \& Keuschnigg (2000)].

For both imports and exports, the expected gains (and pains) will be large if a country's trade is heavily concentrated in goods where barriers are high to start with, and vice versa. Figure 2 therefore also looks at the significance of trade barriers for each country's trade with the CEECs. We have constructed weighted average tariff barriers, using each country's bilateral trade with the CEECs - again expressed in percent of that country's GDP - as weights. We do this on a the 6-digit level of the Harmonized System, which comprises over 5,000 different commodities, using post-Uruguay-round nominal MFN rates. ${ }^{5}$ For imports, we also calculate a weighted average measure of non-tariff barriers. Taking such structural details into account, one observes that the differences across countries are somewhat less pronounced. The Austrian measures of import barriers are down to 2.5 times the EU-level (from 3.5 for the simple trade share), while for Ireland, Italy and Greece, they are higher than the simple trade shares. Figure 2 , of course, gives no more than a quick overview of cross country differences in trade exposure to eastern enlargement. A more systematic treatment of trade effects requires a more ambitious modeling effort to which we turn below.

The difference between EU15 countries is even more pronounced when it comes to migration which draws much attention in public discussions. It is generally assumed that Germany and Austria will be the prime recipients of east-west migration. Based on recent estimates by the European Integration Consortium (2001), figure 3 looks at the stocks of residents and employees

\footnotetext{
${ }^{4}$ Formally speaking, the efficiency gains are of first-order (or rectangular effects), rather than second-order (or triangular effects); see Kohler (2000a, 2000b).

${ }^{5}$ These tariffs have already been targeted by the Europe Agreements, but those agreements must be seen as an integral part of eastern enlargement.
} 
from CEEC10-countries living in various EU15-countries, expressed in percent of the total stocks, respectively, of residents and employees. The estimated number of persons from the CEEC10s resident in Austria in 1998 is 1.27 percent of the Austrian population, almost double the German figure (0.68 percent) which, in turn, is more than double the figure for Sweden and Finland which are 0.30 and 0.23 percent, respectively [see European Integration Consortium (2001)]. The ratios are mostly smaller for employees than for residents, Luxembourg and Greece being the only exceptions. These figures may be interpreted as rough indicators of the extent to which countries are exposed to eastern enlargement on the labor market, and they clearly point to a substantial variation among EU15-countries. Again, they give but a first impression. A more serious effort at quantifying the magnitude and effects of enlargement-induced migration will follow below.

Present member countries will also be quite differently affected by the costs of enlargement. The overall cost may be estimated by looking at the financial framework adopted at the Berlin summit of 1999. Comparing the projected appropriations for payments to the CEEC5s with the increase in own resources, and taking the final year of the framework as the benchmark, one obtains a total cost of 10,48 Bio Euro in constant 1999 prices, or 0.113 percent of EU15 GNP. ${ }^{6}$ However, this estimate suffers from uncertainty about the direct payments to eastern farmers. The financial framework assumes no such payments, but the issue has not been fully settled yet in the ongoing negotiations. One should, therefore, regard the figure as a lower bound. Assuming an extension of status quo policies, and relying on econometric models of EU expenditure policy, we arrive at an alternative estimate of the cost which is higher and which one may view as somewhat more realistic: 0.184 percent (0.370 percent) of EU15 GNP if the Union is enlarged to CEEC5s (to all 10 CEECs). ${ }^{7}$ The resulting burden for an individual member country depends on the strategy that the EU adopts in order to achieve a balanced budget.

\footnotetext{
${ }^{6}$ According to the financial framework, projected payments to new members increase through time, hence the final year is the most expensive one.

${ }^{7}$ The proposal recently submitted to the Council by the Commission is more optimistic than the Berlin 1999 framework as regards the year 2006. Commitment appropriations are projected at 15.966 Bio Euro, down from 16.780 Euro in the Berlin 1999 scenario (in 1999 prices). Payment appropriations are 11.840 Bio Euro, as compared to 14.220 Euro in the Berlin scenario. However, the new framework treats 2006 as year 3 after enlargement, whereas before it was the fifth year after enlargement, which the Berlin summit has assumed to take place in 2002. This is important because payments are assumed to be phased in only gradually. Comparing the new 2006 figures with the Berlin 1999 figures for year 3 after enlargement, one finds an increase by 4.356 Bio (2.720 Bio) Euro for commitment (payments) appropriations; see European Council (1999) and European Commission (2002). It seems questionable whether one should treat the estimates for year 3 after enlargement as appropriate for our calculations which are long-run in nature. Throughout this paper, we therefore stick to our initial estimate based on figures for year 5 post-enlargement.
} 
Obviously, there are alternative strategies, and countries take opposite positions. In Kohler \& Keuschnigg (2000) we have presented the alternative fiscal burden resulting for each individual member country if the EU would increase own resources or, alternatively, down-size the return payments from Common Agricultural Policy, or cut European Regional and Structural Funds. For instance, the more a country now receives from structural funds, the more severely it would be hurt by a financing strategy which heavily relies on adjustments of those funds. We shall return to this question in a numerical way when we extend our empirical results for Germany to other present member countries.

This quick overview clearly shows that eastern enlargement must be seen as a rather complex policy scenario involving virtually all aspects of international market integration, in addition to international transfer payments. Established theory of trade integration holds a presumption of gains from trade, while migration theory similarly emphasizes a surplus for the immigration country. From an incumbent country perspective, these need to be set against the expected transfer burden, in order to see if enlargement holds a net gain. It seems rather obvious that the issue can only be settled by looking at the channels of the various effects in more detail and, ultimately, by implementing empirical models for individual countries. Given the key importance of labor market effects, what we need is a refined model which duly observes labor market imperfections. We have developed such a model including a labor market characterized by job creation, job destruction, and equilibrium search unemployment. The model is specifically geared towards trade and migration effects in a dynamic setting. We use a calibrated version to quantify the effects of enlargement on Germany below. We will then use the German results to derive some rough approximations for the other present member countries. However, the next section will first use a skeletal version of our model to make the key transmission channels more transparent and to build intuition for expected effects on incumbent countries.

\section{A Model Based Analysis}

\subsection{Main Transmission Channels}

The main challenge in quantitative policy evaluation is to construct and empirically implement a model which includes the necessary structural detail required by the specific policy scenario. It must not miss any of the main channels for integration effects which empirical and theoretical work has recognized to be important. Since our focus is on present member countries, and in particular on Germany, we apply a one country, open economy model which takes the world interest rate as given. The model treats Germany as trading with other EU countries, eastern candidate countries, and the rest of the world. Domestic consumption uses home goods, as well as imports from these other regions. It can be viewed as a composite good $C$ with a 
corresponding price index $P$ as in equation (1) of Box 1 . Investment $I$ is similarly composed of home produced and import goods. Taking foreign producer prices $\bar{p}^{m}$ as given, a reduction in tariffs and trading costs reduces domestic demand prices and, thus, boosts imports on account of a substitution effect.

The country is considered large on its export markets and can gain market shares with more competitive prices. This is modeled in terms of regional export demand functions which are downward sloping in export prices relative to foreign producer prices. However, German exports are subject to foreign trade barriers. Obviously, if such protection on against German exports disappears, the economy will experience an export boom. Our model thus captures the familiar trade creation and trade diversion effects stemming from EU enlargement. In addition, it takes into account terms of trade effects which are a further "classic" source of welfare gains or losses from integration. With exports a function of relative prices, the terms of trade are endogenously determined by market clearing, i.e. price $p^{H}$ must adjust to equate supply with domestic and foreign demand for home produced goods. The strength of the terms of trade effect depends very importantly on the price elasticities of import and export demand which are given by the "Armington substitution elasticities" relating to commodity demand. ${ }^{8}$

EU enlargement is widely expected to severely hit sensitive sectors such as paper, wood, and textiles. A further sector surrounded by much anxiety is agriculture where the impact of enlargement importantly depends on how the EU Common Agricultural Policy will treat eastern farmers. In contrast, the more skill and technology intensive sectors should prosper on account of enlarged export markets. Expecting a contraction in the low skilled sectors combined with growth in skill intensive industries, economists and policy makers often predict unfavorable distribution effects on wages and employment of high and low skilled workers. How various sectors are affected, however, depends not only on the skill content of trade flows, but also on the particular sectoral pattern of tariff and trade cost reductions, and on the extent of trade exposure. It is by no means ruled out that enlargement favors some of the sectors intensive in unskilled labor while trade with Eastern Europe is quantitatively less important for a number of skill intensive sectors. In this case, the wage spread might not materialize and unskilled workers might not be noticeably exposed. A meaningful study of these important issues must obviously rely on a multisectoral model with different skill groups. Our model is a useful tool to investigate such distributional effects, since it distinguishes twelve production sectors and two skill classes.

The labor market effects of enlargement are a rather sensitive issue in present member

\footnotetext{
${ }^{8}$ The export demand functions can be rationalized in terms of preferences of foreigners similar to (1). If preferences are the same across countries, the price elasticity of export demand must also be equal to the Armington trade elasticity [see Keuschnigg and Kohler (1996a,b)].
} 
countries. With unemployment already high in Germany, particularly in eastern border regions, the prospects of even higher unemployment resulting from structural adjustment is of great concern to policy makers. While the link between trade and unemployment is not very obvious to analysts, immigration from Eastern accession countries should have a more direct impact on labor market equilibrium. It is thus important to include a rigorous modeling of the equilibrium unemployment rate. Based on the theory of labor market search, our model solves, separately for each skill class, for the equilibrium unemployment rate as the result of job creation and destruction. It this way we can shed new light on these sensitive enlargement issues.

Policy makers in EU15 countries also hope for significant growth effects from enlargement. It is clear from both theory and empirical evidence that integration and trade liberalization importantly affect investment and accumulation [see, for instance, Baldwin and Seghezza (1998)]. It is to be expected, therefore, that the investment channel will be an important factor to shape the overall effects of enlargement on present member countries. Our model is based on neoclassical growth theory with savings and investment reflecting intertemporal trade-offs in consumption and production, and includes exogenous trend growth in labor productivity. Starting from an equilibrium of balanced growth prior to enlargement, we compute the entire trajectories starting from current initial conditions to a new long-run equilibrium. We can thus distinguish between short- and long-run dynamic effects. Investment serves not only as a major engine of growth but is also a prime transmission channel to determine the effects on unemployment.

It has been estimated that EU enlargement imposes a considerable fiscal cost on present member countries. Barring an increase in contribution payments, enlargement will require savings from lower spending on agricultural policy and structural funds. Being visible and easy to comprehend, the expected fiscal costs are a contentious issue. On the other hand, if enlargement holds prospects for stronger growth and stimulates the economies of Western Europe, then these countries should reap an important fiscal dividend in terms of increased tax revenues. The opposite case is, however, equally relevant. A country in the south eastern periphery of the union may not benefit much from integration with central European countries but will nevertheless have to share the fiscal burden. If enlargement is a negative shock to these countries, their tax base will shrink and magnify the cost to the public budget. A balanced view will certainly have to take account of such indirect effects. As our model includes all the major taxes and spending items, it allows to compute the size of a fiscal dividend if it exists.

Finally, the benefits of European integration to a large extent stem from the creation of a large common market which raises competition and allows firms to exploit economies of scale in industrial production. The resulting cost and price reductions together with the pro-competitive output gains are important sources of welfare gains from integration. The same logic now 
applies to Eastern enlargement. Only a model of imperfect competition and increasing returns can capture such pro-competitive effects. In our model, production is subject to monopolistic competition with product differentiation and free entry and exit of firms. Producers derive profit margins by marking up prices over unit costs. In a free entry, zero profit equilibrium, all profits are absorbed by fixed production costs. With fixed costs, firm size is well determined, and increased market demand is satisfied by entry of new producers with differentiated products. The introduction of new goods raises aggregate productivity and further magnifies the expansion of industry.

\subsection{Effects on Present Member Countries}

In putting together these transmission channels, we arrive at a model with rich economic structure that can address the important aspects of the policy scenario. It may seem difficult, however, to interpret the simulation results from such a complex model. Nevertheless, the main logic can easily be stated in terms of a few equations as in box 1 where the model is collapsed to a stylized one sector economy. The appendix derives more formally some basic comparative static results. With unrestricted capital mobility, the interest rate $r$ is mainly fixed internationally. In dismantling import barriers $\tau^{E}$, eastern enlargement reduces the domestic demand price $p^{E}=\left(1+\tau^{E}\right) \bar{p}^{E}$ of goods of eastern origin. Depending on the share of eastern capital goods in domestic investment spending, import liberalization contributes to a lower price $P$ of the composite capital good. As the acquisition price of capital falls short of the present value of the extra profits in (5), producers start to invest in new equipment. Capital intensity will eventually rise and thereby depress the marginal return to investment until new investment just breaks even at the margin again.

The higher capital intensity raises labor productivity $F_{L}$ which, together with the lower composite goods price, boosts the surplus $R^{L}$ from job creation in (6). Depending on the outcome of wage negotiations, producers appropriate a job rent $R^{L}-W$ from new hiring while the worker claims a wage $W$. To expand the workforce, firms must post vacancies and recruit in the labor market. Depending on market tightness $\theta$, the firm is able to locate a suitable worker with instantaneous probability $q$ while it must otherwise continue to search. Such recruitment activities are costly and require the firm to divert $\kappa$ units of labor per vacancy from production. The ensuing output loss is the opportunity cost of recruitment. When investing in an additional vacancy, the firm thus compares the marginal cost of a vacancy, $\kappa R^{L}$, with the expected present value of the producer rent $R^{L}-W$ that accrues, with probability $q$, once a worker is found and production starts with the filled job, see (7). In raising the job surplus $R^{L}$, integration inflates the opportunity cost of recruitment but also strengthens the return to labor market search, i.e. the expected present value of the producer rent. 
When wages are sticky because, for example, unemployment benefits are kept constant in real terms, the expected present value of producer rents increases more than proportionately. For any given labor market tightness $\theta$ and a corresponding hiring probability $q$, it becomes increasingly attractive to post more vacancies to expand the workforce. As firms need to fill more vacancies and accordingly expand recruitment, the labor market tightens which, in turn, makes it increasingly difficult to find appropriate workers. The hiring probability falls, $q^{\prime}(\theta)<0$, until the investment condition for vacancies is restored again in the new equilibrium. While bad for firms, tight labor markets, of course, improve the prospects of the unemployed to find a job, $f^{\prime}(\theta)>0$. According to (2), for this reason, the outflow from unemployment starts to exceed the inflows until, after some adjustment period, a lower equilibrium unemployment rate is attained. The higher employment combines with higher capital intensity to considerably expand capital accumulation and output, see (3) and (4) in Box 1.

So far, we have taken as given the prices of home produced goods, $p^{H}$. It is not clear a priori how they will change since the scenario holds a negative demand shock as domestic spending shifts to imports, but also stimulates export demand. It turns out that our scenario holds more potential on the export side and, thus, creates excess demand for home goods. In this case, domestic producer prices must increase to bring about market clearing which will be verified in the simulations below. Higher domestic prices directly boost the marginal return to investment. On the other hand, they also raise the capital goods price $P$, but only less than proportionately, since investment uses partly home goods but also import goods. According to (5), investment incentives must further improve. Capital intensity picks up which, in turn, boosts job rents and thereby induces firms to post more vacancies, see (6-7). Unemployment declines and output expands. If, indeed, enlargement on average strengthens domestic producer prices, the supply side expansion should be even more pronounced.

Imperfect competition introduces another important magnifier. With fixed costs in production and free entry of producers, the size of individual firms is well determined. An industry wide expansion is then largely achieved by entry of new firms which introduce new differentiated products, rather than by output growth of existing firms. Therefore, the number of firms depends on aggregate output, $n(Y)$, which, in turn, is related to factor endowments. A larger number $n$ of goods and services results in gains from specialization and reduces the cost of the composite investment/consumption good, $d P / d n<0$. By (5-7), such productivity gains stimulate investment and employment and thereby boost aggregate output $Y$ as in (3). This output gain is again brought about by new firms, $n(Y)$, which further raises productivity and stimulates even more investment, employment and output. Monopolistic competition thus importantly magnifies the 
investment response. ${ }^{9}$

Finally, we can shortly explain the expected labor market effects from immigration. In the short-run, immigration must raise the unemployment rate by definition since the newly arriving foreign workers must first search in the labor market and will find a job only after some transitory search period. Given the fast labor market dynamics, the short-run increase in unemployment should disappear rather quickly. In the long-run, increased labor supply on account of a larger stock of immigrants fails to affect equilibrium search unemployment. ${ }^{10}$ Immigration does not directly affect the investment conditions in (5) and (7) for equipment and job vacancies. In (2), the long-run unemployment rate is independent of the increased labor force $N$. Both the number of employed and unemployed workers expand proportionately, leaving the unemployment rate unchanged. Since the vacancy condition (7) is not affected either, equilibrium labor market tightness remains invariant as well. In the long-run, firms simply expand the number of vacancies $V$ in proportion to employment. According to (5), investment accommodates the increased employment without any effect on capital intensity. Output thus expands by the same proportion. If there were no increasing returns, the adjustment mechanism would be completed. If, however, the output gains lead mainly to entry of new firms and a larger product variety $n(Y)$, the resulting gains from specialization will reduce the cost $P$ of investment goods and thereby strengthen investment incentives, see (5). Job rents should increase along with higher capital intensity and trigger increased recruitment by firms. Via this channel, immigration might well reduce the long-run unemployment rate, rather than increase it as much of the popular opinion seems to believe.

\section{Box 1: Main Transmission Channels}

We distinguish four regions, Home, European Union, Eastern accession countries, and Rest of the world. Demand for home and import goods, $c^{H}$ and $c^{m}$, is derived from (homothetic) preferences

$$
C=C\left(c^{H}, c^{U}, c^{E}, c^{R}\right), \quad P=P\left(p^{H}, p^{U}, p^{E}, p^{R} ; n\right), \quad d P / d n<0,
$$

where domestic prices of imports include tariffs and other trade barriers, $p^{m}=\left(1+\tau^{m}\right) \bar{p}^{m}$. Foreign producer prices $\bar{p}^{m}$ are taken as given. $P$ denotes the consumer price index which depends not only on prices but also on product variety $n$, i.e. the number of differentiated products. The modeling of regional trade flows is completed by adding export demand functions $e^{f}=e\left(p^{H}\left(1+\tau^{f}\right) / \bar{p}^{f}\right)$, that are downward sloping in the price of domestic exports, inclusive of trading costs, relative to foreign prices.

\footnotetext{
${ }^{9}$ See Keuschnigg (1998) for a more detailed analysis.

${ }^{10}$ One might imagine, however, that institutional changes affect workers' bargaining power or mismatch in the labor market increases. Both shocks would to some extent affect the long-run unemployment rate.
} 
Savings and the level of consumption follow from maximization of life-time utility of overlapping generations of households, see the appendix. Savings and consumption thus respond to interest rates and reflect the time profile of expected future wage earnings. Disposable wage income is an average over wages and unemployment benefits and, thus, is low when unemployment is widespread. Aggregate labor market flows are

$$
\dot{U}_{t}=N_{t, t}+s L_{t}-\left(f\left(\theta_{t}\right)+\beta\right) U_{t}, \quad \theta_{t} \equiv V_{t} / U_{t}
$$

Inflows into the pool $U_{t}$ of unemployed result from arrival of $N_{t, t}$ new agents and job destruction at rate $s$. The outflow consists of unemployed workers finding a job at rate $f\left(\theta_{t}\right)$ or dying at rate $\beta$. Absent immigration and with population constant, $L_{t}+U_{t}=N$. Given a birth rate equal to the mortality rate $\beta$, the number of labor market entrants is $N_{t, t}=\beta N$ which implies a stationary unemployment rate $U=(\beta+s) /(f(\theta)+\beta+s)$. The unemployment rate is driven by labor market tightness $\theta$, measured by the ratio of vacancies $V$ to job seekers $U$.

Production uses capital $K$ and labor $L^{D}$, giving output $Y$

$$
Y_{t}=F\left(K_{t}, L_{t}^{D}\right), \quad L_{t}^{D}=L_{t}-\kappa V_{t} .
$$

To fill jobs, firms must post vacancies $V$ and divert a part $\kappa V$ of the workforce to search and recruitment activities, leaving only $L^{D}$ for production. New hiring is $q V$ since only a fraction $q$ of vacancies can be filled at each instant. Hiring and investment $I$ accumulate stocks by

$$
\dot{L}_{t}=q\left(\theta_{t}\right) V_{t}-(s+\beta) L_{t}, \quad \dot{K}_{t}=I_{t}-\delta K_{t},
$$

where $\delta$ is the rate of depreciation. Investment is also a composite of regional goods as in (1). The hiring rate declines with equilibrium labor market tightness, $q^{\prime}(\theta)<0$.

Value maximization by firms determines optimal investment which equates the acquisition cost of new capital $P$ with the present value of marginal capital income,

$$
\frac{\left(1-t^{Y}\right) p^{H} F_{K}}{r+\delta}=P\left(p^{H}, p^{U}, p^{E}, p^{R} ; n\right)
$$

where $F_{K}$ and $F_{L}$ are marginal factor products, $t^{Y}$ the income tax rate, and $r$ a fixed interest rate. Investment determines capital intensity and, in turn, the job surplus

$$
R^{L}=p^{H} F_{L} / P\left(p^{H}, p^{U}, p^{E}, p^{R} ; n\right) .
$$

The investment condition for new vacancies equates the opportunity cost of recruitment, $\kappa R^{L}$, and the expected present value of the firm's net of tax job rent $\left(1-t^{Y}\right)\left(R^{L}-W\right)$, i.e.

$$
\frac{\left(1-t^{Y}\right)\left(R^{L}-W\right)}{r+\beta+s} \cdot q(\theta)=\kappa R^{L}
$$

The firm posts vacancies until the marginal cost $\kappa R^{L}$ of recruitment in terms of foregone output equals the firm's expected value of the vacancy which equals the probability $q$ of finding a worker times the expected present value of the job rent accruing to the firm. The instantaneous discount rate reflects the risk of job termination due to death, $\beta$, and job separation for other reasons, $s$. 


\section{Simulations With a CGE Model: The German Case}

While revealing important insights, analytical treatments based on stylized models leave open the central question raised in section 2: Will the integration gains outweigh the fiscal burden? Even though the central force behind enlargement is political in nature, whereby enlargement should not be subject to net gains on the part of all incumbents, the process can be moved to more solid ground if the public and policy makers are provided with quantitative measures of key economic effects. We therefore proceed to an empirical analysis based on a CGE model of the German economy, extending the work of Keuschnigg et al. (2001). To the best of our knowledge, this is the first multisectoral CGE model combining savings and investment with search-unemployment in segmented labor markets for high and low skilled labor. Appendix A.7 describes the most important elements of the computational model and its calibration. We now present the enlargement scenario as it enters the simulation model and then discuss the impact of enlargement on Germany. In a subsequent section we broaden our focus to all EU15 countries.

In political terms, Germany is a staunch supporter of enlargement. At the same time, it is seriously concerned about unwelcome economic effects, particularly with respect to migration. As we have seen in section 2 , it is particularly exposed to new member countries from CEE on both its commodity and labor markets. Thus its imports from CEECs in 1997 were 1.5 percent of its GDP, second only to Austria which has a share of 2.7 percent. The corresponding figure for German exports to CEEC10s is 1.83 percent, which is surpassed only by Finland with 2.71 percent and Austria with 3.98 percent. While Germany is a particularly interesting case to look at, these figures at the same time tell that even for Germany enlargement affects only a relatively small fraction of GDP. Existing trade flows thus constitute a low leverage for specific measures of commodity market integration in the process of EU enlargement. One does not expect overly strong integration effects emanating from commodity markets. However, the same is not necessarily true for labor markets. To proceed with a closer investigation of the German case, we must now describe the specific scenario that we address with our computational model.

\subsection{The Scenario}

In section 2 we have identified three different components of an enlargement scenario: trade integration, a fiscal burden from the cost of enlargement, and east-west migration. The trade and fiscal aspects of our simulation scenario largely follow the pattern of Keuschnigg et al. (2001). Table 1 summarizes the overall scenario which is best understood as being in four parts. The first element implements the Europe Agreements which removed non-agricultural tariffs on trade between the EU15 and CEEC10s. Removal of tariffs on EU15 imports has been put into effect in January 1997, while tariffs on CEECs' imports will be completed in 2002. Strictly speaking, 
these agreements are not a matter of membership. In a broader sense, however, they must surely be seen as an integral part of the enlargement project. For this reason we include them in our simulation scenario. The next measure of trade integration removes of all remaining tariffs and extends the Single Market in the event of enlargement by eliminating technical barriers and other obstacles to market access. In line with other studies, we model this as a reduction in real trading costs, and assume a 5 percent (ad-valorem) reduction of such costs on a sectoral average. ${ }^{11}$ Our scenario restricts this to the Luxembourg group of CEEC5-countries. Although these are the most promising CEE-candidates in the "Helsinki race", recent events indicate that the first round of enlargement will include 8 CEECs (CEECs5 plus Latvia, Lithuania and the Slovak Republic) plus Malta and Cyprus. All of these other countries are of minor importance, however. It thus seems justified to restrict our attention to the CEEC5s only. Trade integration also holds repercussions for EU15 farmers. In Keuschnigg et al. (2001) we argue that extending the CAP price support system to new members is likely to increase import prices for eastern farm products by 0.61 percent. For a similar reason subsidies on agricultural exports to CEECs will be abolished. Finally, the CAP-induced supply response of eastern farmers is generally expected to lower world farm prices. In line with Anderson \& Tyers (1995), we assume a 2 percent price cut. ${ }^{12}$

The second component of our scenario captures the cost of enlargement. As detailed in Kohler \& Keuschnigg (2001), for any country the fiscal burden varies greatly, depending on whether budget balance in an enlarged Union is achieved through an increase in contribution payments, a cut in CAP return flows, or by downsizing the ESF. Moreover, an econometric model of EU expenditure yields a somewhat higher overall cost of enlargement than the official financial framework of the Union adopted at the Berlin summit in 1999. Our scenario includes an overall cost of 0.184 percent of EU15 GDP and assumes that the budget will be closed by a cut in ESF payments. In this case, a CEEC5 enlargement implies that Germany's net contribution payments to the Union rise from $0.595 \%$ of its GDP to $0.665 \% .{ }^{13}$

The third and fourth components of the scenario turn to migration. Estimating migration flows from CEECs to the EU15 countries is notoriously difficult. We make use of a recent study by the European Integration Consortium (EIC, 2001) in order to derive a migration scenario that is amenable to our simulation model. To make full use of our model which features a

\footnotetext{
${ }^{11}$ This is considerably less optimistic than the 10 percent assumed by Baldwin et al. (1997).

${ }^{12}$ Our scenario reasonably assumes that the EU will not raise its variable import levies and export subsidies to protect its farmers against this erosion of world market prices. Keuschnigg et al. (2001) offer more detail on CAP effects of enlargement.

${ }^{13}$ In Keuschnigg et al. (2001), we have used the more optimistic Commission estimate in which case the net contribution increases only to $0.645 \%$.
} 
distinction between skilled and unskilled labor, we use additional information to arrive at a scenario which duly recognizes that distinction. The EIC baseline projections imply an overall increase in German residents from CEEC10s from some 550 thousand in 1998 to about 2.5 Mio people by 2030. Assuming in line with EIC that 35 percent of these residents will enter the German labor force, we arrive at a long-run increase of the skilled and unskilled labor force by $0.84 \%$ and $6.15 \%$, respectively. The details of our procedure can be found in appendix A.7. ${ }^{14}$ Formally, the migration scenarios add the accumulated migration inflows to the initial stocks to obtain the new steady state levels of skilled and unskilled labor, respectively. In line with migration theory and EIC projections, we assume, instead of an instantaneous stock adjustment, that migration inflows accumulate over time and augment stocks gradually.

\subsection{Results}

Due to its complexity, the enlargement scenario in its entirety is ambiguous a priori. The abolition of trade barriers tends to expand the economy, while higher net transfers to the EU are contractionary [see Keuschnigg and Kohler (1996a,b)]. Our results indicate that the mutual trade liberalization and improved market access clearly dominate the picture. The supply and demand reactions following enlargement are easily pointed out. Despite of a rather more complex economic structure, the numerical results largely confirm the basic insights of the analytical insights of section 3 and the appendix. The base case scenario keeps real unemployment benefits and tax allowance constant. Table 2 separately presents the long-run (steady state) effects for the trade and fiscal scenarios in columns 1 and 2, while column 3 depicts the joint effect of both. The interpretation of column 3 (Enl) runs as follows.

Real Benefits Constant: Cheaper capital and intermediate goods improve supply conditions. In addition, demand favors imports of eastern origin, hence there is downward pressure on domestic producer prices. At the same time, the mutual elimination of tariff and non-tariff barriers boosts demand for German exports to the CEECs. Indeed, the scenario entails a slightly more powerful leverage on the export side, due to higher tariffs in CEECs than in the EU [see above]. To restore equilibrium, domestic producer prices increase on average, although the effect is rather small compared to the reduction in price indices on account of lower protection rates. ${ }^{15}$ German exports to CEECs expand by about 57\%. Higher prices reinforce the supply

\footnotetext{
${ }^{14}$ Refined estimations by Sinn et al. (2001) lead to higher immigration flows, see also Sinn \& Werding (2001). We use the EIC estimates because they extend to other EU15 countries, as we require in section 5.

${ }^{15}$ The large terms of trade gains vis-à-vis the CEEC5s (7\%) are due to the fact that vanishing trade costs are direct equivalents to a terms of trade improvement. Since cheaper imports reflect savings in resource use on the
} 
side expansion by strengthening investment incentives, whence the economy experiences an investment led expansion with capital stocks accumulating by $0.63 \%$. The increase in capital intensity strengthens marginal rents to job creation and tightens labor markets, leading to a small reduction in unemployment in the base case where real unemployment benefits are kept constant. The reduction in the unemployment rate is slightly larger for unskilled workers, albeit from a higher initial rate. With a total benchmark labor force of 40 million, the reduction in the average unemployment rate corresponds to 28.000 new jobs. While the gains in employment are relatively minor, workers benefit from higher wages. Wages of skilled workers, deflated by the consumer price index, are up by $0.92 \%$ in real terms. Notice that in the German case, unlike the Austrian, goods market integration contributes to a slightly wider wage spread. ${ }^{16}$

The output expansion largely occurs via firm entry and thus contributes to productivity gains due to specialization and diversification of industrial production. Such productivity gains translate into lower price indices which further stimulate investment and other final demand, thereby magnifying the gains in output and real income. Real GDP, deflated by the consumer price index, is up by $0.67 \%$. We capture the government budget effect by assuming that the government passes on the fiscal burden of enlargement to households by cutting transfer payments. At the same time, however, the overall expansion swells the tax bases which, for given rates, boosts revenues from both direct and indirect taxes. This revenue effect in the end allows for a remarkable increase in transfers to households other than unemployment benefits $(0.52 \%$, or $0.82 \%$ in real terms). The fiscal returns from enlargement are, thus, more than enough to pay for the increase in net contributions. Wage growth, lower unemployment and higher transfers all boost average disposable wage income which is up by $0.85 \%$ in real terms. By construction of the model, this is exactly mirrored by a corresponding increase in consumption in the long-run. Finally, and perhaps most importantly, Table 2 reveals that the goods market implications of enlargement promise aggregate welfare gains which more than offset the fiscal cost of enlargement. The net effect is measured by a Hicksian equivalent variation of almost half a percent of German GDP. ${ }^{17}$

\footnotetext{
part of eastern suppliers, there is no offsetting terms-of-trade loss for the east!

${ }^{16}$ The effect on the wage spread is understood only by investigating in more detail the structural effects of enlargement, see Keuschnigg et al. (2001). For the Austrian case, see Keuschnigg \& Kohler (2002) and Kohler \& Keuschnigg (2001).

${ }^{17}$ We compute the equivalent variations of life-time wealth for each cohort and sum them over present and future generations with due discounting and weighing by cohort size. For comparison with annual GDP, we convert the resulting wealth measure into an annuity by multiplying with the interest rate.
} 
Alternative Fiscal Policy Assumptions: In discussing Proposition 1 of appendix section A.6, we argued that integration should no longer affect unemployment when unemployment benefits as well as tax allowances are fully indexed to net wages. As a theoretical possibility we noted that unemployment rates may even increase when unemployment benefits are indexed but wage tax allowances are kept constant in real terms. Before turning to the migration scenarios in columns 4 through 6 of Table 2, we numerically investigate the role of domestic fiscal policy rules in determining how unemployment responds. Column 1 of Table 3 repeats 'Enl' from the previous table. Column 2 depicts the case where both unemployment benefits and basic tax allowance are indexed to net of tax wages. In this case, wages are fully flexible and integration remains without consequences for labor market tightness and unemployment. The difference in other variables is hardly discernible, except for government transfers which are roughly halved, since indexation requires an increase in unemployment benefits in face of higher wages. For this reason, the gains in average disposable wage income and consumption are somewhat lower. Moreover, the welfare gain is partially eroded, since the shock is now less expansionary which tends to subdue the gains from specialization and induced capital accumulation.

Next, we re-calibrated the model to allow for a more progressive wage tax with higher marginal tax rates which combine with a larger personal allowance to replicate the data on tax revenues. Then we repeated the enlargement shock, keeping the real value of the basic tax allowance constant while introducing indexation of unemployment benefits. As anticipated in appendix section A.6, we find in column 3 that unemployment rates (slightly) increase in response to the enlargement shock. Column 4 of table 3 again turns to the base case scenario where benefits and the tax allowance are kept constant in real terms. In addition, we now keep constant real household sector transfers as well (which decline along with the consumer price index by $-0.32 \%$ ) and, instead, adjust the wage tax to finance the government budget. The expansionary nature of EU enlargement swells the tax bases and yields a considerable fiscal dividend which allows for a reduction in the marginal wage tax rate by about one percentage point. The lower tax burden on labor reinforces the effects of integration and further squeezes unemployment. Compared to the base case scenario in the first column of Table 3, the reduction in the unemployment rate is now more than double, creating employment for about 63.000 people.

Immigration: Columns 4 and 5 of Table 2 turn to immigration of low-skilled and high-skilled workers separately, while column 6 depicts the joint immigration scenario. The effects reported in column 6 are anticipated in Proposition 3 of appendix section A.6. In an open economy with a constant real interest rate, immigration doesn't hold any direct incentives to adjust capital intensity. The increase in manpower is largely accommodated by investment to hold the capital labor ratio constant. Consequently, immigration translates into an equally large 
output expansion. In the presence of a monopolistically competitive market structure with endogenous diversification, however, the output gains come in the form of increased firm entry, resulting in more specialized production techniques. The gains from diversification squeeze price indices which makes investment goods cheaper and contributes to higher capital intensity and labor rentals. With constant real benefits, higher labor rentals increase job values by more than wages, encouraging firms to post more vacancies. Tightening labor markets would eventually reduce unemployment rates in both skill groups if immigration had no skill bias. Since immigration is concentrated in the low skilled segment, however, we find that only the high skilled experience a lower unemployment rate while unemployment among low skilled workers becomes more widespread. Due to the size of the shock, the effects are much stronger than in the base scenario of column 3. It must be emphasized that the welfare gains in the migration scenario relate only to the domestic population and correspond to what migration theory calls the "immigration surplus".

Columns 4 and 5 of table 2 point to strong distributional effects when immigration is concentrated in the low-skilled sector, or in high-skilled sector of the labor market. The differential effect of unskilled immigration on the unemployment rate of low-skilled workers is more than half a percentage point, while at the same time the wage rate of those employed falls by more than 4 percent! Skilled workers, in contrast, benefit from a 1.17 percent wage increase (almost $2 \%$ in real terms), while their unemployment rate at the same time falls by one tenth of a percentage point. Most of the shock thus translates into wages rather than (un-)employment. A particularly noteworthy feature of the two separate scenarios of columns 4 and 5 is the following. Immigration of low-skilled workers lowers unemployment for skilled, while raising it for unskilled labor, as expected. But high-skilled immigration lowers unemployment for both types of labor. This might be due to the fact that skilled labor is complementary to capital, in which case immigration causes a marked expansion of the capital stock. Indeed, the capital stock increases by more than 1 percent in column 5 , almost as much as with unskilled migration, although the inflow is much lower in magnitude than for unskilled labor [see above].

Figures 4a-b compare the transitional effects on group specific unemployment rates for the two differential migration scenarios, the stock and flow approaches. The flow approach assumes a permanently higher arrival rate of new generations at home. The resulting adjustment process is smooth, but extends over several decades until the stationary population is attained. The stock approach, in contrast, assumes that immigration inflates all age cohorts proportionately without any extended demographic effects. Since all migrants find employment only by searching in the labor market, the unemployment rate shoots up instantaneously to more than double its initial value. Due to the very fast labor market dynamics, however, the long-run unemployment rate of about $10.5 \%$ is approximately attained within a few quarters. 
Sensitivity: As in any economy wide model, results are sensitive to some extent to parameter variation. Although the number of parameters in a detailed empirical model is large, comparative static analysis based on stylized versions of the model, as well as previous experience with simulation work, narrow down the set of sensitive parameters quite considerably. Rather than adding more simulations, we may therefore refer the reader to our earlier work for a more detailed treatment of the sensitivity issue. Generally, we can identify two sources of sensitivity. One is in the choice of some key behavioral parameters, and the other is in the specification of the policy scenario. In Keuschnigg et al. (2001) we have found that scaling down the Armington trade elasticities by a factor of 0.8 reduces the aggregate welfare gains by a fourth. ${ }^{18}$ Of course, an increase in these elasticities would yield a considerably more positive picture, see also Keuschnigg and Kohler (1996b). A further important feature of our model is increasing returns due to monopolistic competition. The key parameter here is the elasticity of substitution among differentiated varieties of a product, the so-called Dixit-Stiglitz elasticity. A larger elasticity makes the perceived demand curve of individual producers more price elastic and reduces market power. Furthermore, the external productivity gains from specialization in production become smaller. Such productivity gains act as important magnifiers. Not surprisingly, we find that doubling the elasticity as compared to the base case reduces welfare gains by a third. Finally, Heijdra and Keuschnigg (2000) have found that the comparative static effects of enlargement are not very sensitive to variations in the matching elasticity and the bargaining power of workers, even though these are key parameters in determining the overall unemployment rate. Overall, we may conclude that the qualitative results are very unlikely to be turned around if we re-calibrate the model with rather different parameter values.

Very important, but often neglected, is the sensitivity of results with respect to particular assumptions included in the policy scenario. The size of real trade cost reductions are subject of much debate. We have chosen rather conservative estimates, i.e. a 5 percent reduction on average as compared to 10 percent in Baldwin et al. (1997). As evidenced by Table 2, the reduction in real trade cost clearly dominates the overall picture. Our results would be much more beneficial, for instance, if we were to follow the more optimistic assumptions taken in Baldwin et al. (1997). Finally, Table 3 points to the importance of domestic fiscal policy rules in determining the impact of enlargement. Complete indexation of unemployment benefits would eliminate the effects on unemployment. On the other hand, if real benefits were kept constant and the revenue proceeds used to reduce the wage tax instead of cutting neutral transfers to

\footnotetext{
${ }^{18}$ The Armington elasticities directly affect the power with which the trade shock is transmitted to the home economy. Lower values make import and export demand less price elastic which magnifies the relative price changes but dampens the quantity response.
} 
households, the beneficial effect would be considerably magnified.

\section{Implications for Other Member Countries}

Germany is but a special case. It is important to also look at other countries, duly taking into account how they differ from Germany in terms of enlargement-related characteristics. Following an approach that we have developed in Keuschnigg \& Kohler (1996b), we therefore venture to extend the above results to other incumbent countries. To do so, we use the results obtained above in order to derive key elasticities with respect to certain elements of the enlargement scenario that can be applied to other countries, given sufficient scenario details pertaining to these countries. We focus on the four scenario components highlighted by table 1: Trade integration (scenario I), the fiscal burden arising from budgetary implications (scenario II), and immigration from new member countries, separating low-skilled labor (scenario III) from skilled labor (scenario IV). We thus require country-specific details on each of these aspects.

The key idea is that the magnitude of the enlargement shock differs across present member countries because they differ (a) in their volume and composition of trade with accession countries, (b) in their likely share of the fiscal burden that is allocated to them, and (c) in the number of immigrants they are likely to attract. Once we have constructed measures for the size of country-specific enlargement shocks, including Germany, we first take the results (for welfare, say) from our computational model to calculate elasticities with respect to these shocks, and then apply these elasticities to other countries' enlargement shocks. Admittedly, this yields but a rough approximation, but barring detailed computational models for all 15 incumbents it is certainly a very useful and informative exercise.

The approach is best described by means of direct reference to table 4 which presents welfare results, but it can easily be applied to any other variable of interest. In Table 2, we decompose the overall scenario into its relevant components. Columns 1 through 4 of Table 4 correspond to columns 1-2 and 4-5 of Table 2. Consider first the trade component of our scenario. Integration of commodity markets has different effects for each of the EU15 countries, depending on how much they trade with accession countries, but also on the detailed patterns of this trade. Thus, for some EU15 countries trade with CEECs may be focused on goods where barriers are particularly large prior to eastern enlargement, while trade of other incumbents may be concentrated in goods with relatively low barriers. This holds true for tariff and non-tariff barriers, and it applies independently to exports and imports of each country. An adequate measure of the countryspecific size of the enlargement-induced trade-shock needs to take all of this into account. We rely on Kohler (2000a) where several theory-based measures of this kind are presented for all EU15 countries. These are constructed from weighted averages of tariff- and non-tariff barriers, 
using each country's trade with CEECs, expressed as shares in its own GDP, as weights. This is done independently for both imports and exports, based on the 6-digit level of the Harmonized System (HS) which comprises over 5,000 different commodities. To obtain a more comprehensive measure, such averages are then combined with indices which capture the possibility of trade diversion. ${ }^{19}$

The first column of Table 4 reports the country-specific trade shock in terms of a composite index of trade exposure to CEECs (see previous footnote). For Germany, the index value is 0.397. At the same time, column 1 Table 2 reports from our computational model that the German welfare gain from enlargement-induced trade integration is 0.554 percent of GDP. This implies an elasticity value of $1.394=0.554 / 0.397$, which is reported in the last line of Table 4. To obtain an estimate for the corresponding welfare gain for France, we take this elasticity value and multiply it with the size of the French trade shock which according to our composite measure is 0.103 . The result is a welfare gain in the amount of $0.143(=0.103 \times 1.394)$ percent of GDP. The implications for other incumbent countries are calculated in the same way. To save space, Table 4 does not report these values for each component of our scenario. Instead, we list the country-specific shocks for all three remaining elements of the enlargement scenario, reporting the net welfare effect in the final column.

The German model elasticities for other scenario elements are derived in a similar way. For instance, column 2 of Table 4 reports the size of the fiscal burden from the budgetary cost of eastern enlargement to the EU15. We rely on an econometric model of EU expenditure policy which explains return flows through CAP as well as European structural and regional funds (ESF), in terms of receiving countries' economic characteristics, see Breuss (1995). ${ }^{20}$ Based on the estimated coefficients of this model, the relevant economic variables of the CEECs yield an estimate of CAP and ESF expenditure to be allocated to new members. Subtracting the CEECs' own resources, we arrive at the cost of enlargement that EU15 countries have to share, either by increasing own resources, or by downsizing CAP or ESF spending. Our calculations

\footnotetext{
${ }^{19}$ For instance, the average tariff barrier relating to an EU country $j$ is $\sum_{i} \mu_{i}^{j} t_{i}$, where $t_{i}$ is the common external tariff in commodity $i$, and $\mu_{i}^{j}$ denotes commodity-i-imports from CEECs into country $j$, expressed as a share in country $j$ 's GDP. Analogous calculations are made for non-tariff barriers, and for exports to CEECs. The data source is the OECD International Trade by Commodity Statistics (ITCS) data bank (on CD-DOM), and the corresponding OECD Indicators of Tariff and Non-tariff Barriers (on CD-ROM), as well as Finger et al. (1996). In terms of the notation used in Kohler (2000a), the overall measure used and reported in table 4 is composed of the indices $\bar{T}_{O}^{j}+\bar{K}_{O}^{j}+\bar{N}_{O}^{j}+\bar{X}^{j}$. There is no immediate interpretation of this composite index, but this does not in any way harm its use in the approach described above. Notice also that the index is more comprehensive than the measures underlying Figure 2 above.

${ }^{20}$ The resulting cost estimate is somewhat higher than the Commission estimate evidenced in the financial framework for 1999-2000 [see Kohler \& Keuschnigg (2000)].
} 
are based on the assumption that the enlarged Union will cut its ESF spending to balance the budget. ${ }^{21}$ The resulting fiscal burden for each of the EU15 countries is expressed in percent of its GDP which is reported in column 2 of Table 4. For Germany, we have a fiscal burden equal to 0.07 percent of GDP (see also Table 1). Table 2 reports a welfare loss from this burden in the amount of 0.091 percent of GDP. This corresponds to an elasticity of $1.309=0.091 / 0.070$ which is again found in the last line of Table 4. Since Portugal would lose ESF return flows worth 1.025 percent of its GDP under this scenario, it would sugger a welfare loss equal to -1.342 $(=-1.025 \times 1.309)$ percent of GDP.

As regards enlargement-induced migration, we rely on estimates reported by the European Integration Consortium (2001) to obtain expected immigration flows for all EU15 countries. Given our model focus on skilled versus unskilled labor, we aim at a corresponding breakdown of migration flows. Relating the projected skilled and unskilled migration inflows to the receiving country's skilled and unskilled labor force, respectively, we arrive at estimates of the skill-specific migration shocks as reported in columns 3 and 4 of Table 4 . Details of the underlying procedure can be found in the appendix. For Germany, the estimates imply that the unskilled labor force increases by 6.152 percent, while immigration swells skilled labor supply by 0.840 percent. Comparing with columns 4 and 5 of Table 2 , we obtain welfare elasticities of $0.058=0.357 / 6.2$ for immigration of low skilled labor, and $0.399=0.335 / 0.840$ for high skilled immigration. These elasticities are again reported in the last line of Table 4. Applying these to expected Spanish immigration flows, for instance, the welfare effects from low skilled immigration into Spain is $0.018(=0.312 \times 0.058)$, and for skilled migration it is $0.015(=0.037 \times 0.399)$.

Finally, we arrive at the total welfare effect of a specific country by summing up the elasticities reported in the last line multiplied with the corresponding shock components as reported in columns 1 to 4 of Table 4 . Thus, for Germany, we calculate an overall welfare effect of $1.151=$ $0.397 \times 1.394-0.070 \times 1.309+6.200 \times 0.057+0.800 \times 0.419$ percent of GDP. Note that the first two parts of this sum give a welfare increase of 0.462 percent of GDP, ${ }^{22}$ while immigration overall results in a combined welfare effect of 0.689 percent.

Figure 5 visualizes the overall welfare impact of present member countries and also relates it to the separate sources of gains or losses. A comparison with other countries reveals a great deal of variation and reveals the conflict of interest that we have alluded to above. The welfare gain

\footnotetext{
${ }^{21}$ For more details and alternative calculations, see the appendix to Keuschnigg \& Kohler (1999), as well as Kohler \& Keuschnigg (2000).

${ }^{22}$ The difference between this figure and the welfare effect in column 3 of Table 2 is due to the nonlinear nature of the computational model. Fully solving the computational model is bound to generate results which are not directly reproduced by simply adding the elasticity-based sub-results.
} 
from trade integration comes close to 1 percent of GDP for Austria and exceeds half a percent for Germany and Finland, while being almost negligible for Portugal and Spain. Trade integration with CEECs is expansionary for all countries, but again only marginally so for countries which are less exposed to the east. The fiscal implications from the cost of enlargement are also quite uneven across present member countries. Specifically, when the budget of the Union is balanced through ESF cuts, several countries must shoulder a large burden, although they stand to benefit only well below average from integration gains. Notice that the welfare elasticity is larger than one, i.e. the welfare loss of a country is higher than its share in the fiscal burden. The general equilibrium repercussions make net outward transfers a contractionary "policy" for the domestic economy.

Country differences are most pronounced when it comes to migration. According to the EIC (2001) estimates, accumulated migration inflows vary from almost nil in countries like Spain and Portugal to as much 10 percent for unskilled labor in Austria, or 6 percent in Germany. From a policy perspective, a notable feature of the immigration scenario is that it yields both negative and positive effects. On the one hand, Table 4 points to a sizable welfare gain that immigration yields to the domestic population of the receiving country - the familiar "immigration surplus". On the other hand, immigration of low-skilled labor does contribute to domestic unemployment as we discussed in the case of Germany. Note again, however, that high-skilled immigration is different in that, in fact, it lowers unemployment for both types of labor; see Table 2 above.

The approach is easily extended to other variables of interest. Thus, for the trade scenario table 2 reports an increase in government revenues (measured by a notional increase in lumpsum transfers to domestic households) of 1.167 percent which yields a revenue elasticity equal to $2.936=1.167 / 0.397$. Assuming somewhat heroically that the Spanish fiscal structure is reasonably similar to the German one, we would calculate that the expansionary trade shock would boost Spanish government revenue by $0.168(=0.057 \times 2.936)$ percent. This is low compared to the German estimate, since Spain is trading only to a minor extent with CEECs and, therefore, cannot be stimulated very much by trade integration. For shortage of space, we do not report any results other than the overall welfare effects reported in Table 4 . The reader may compute any result of interest by relying on the country-specific shocks reported in Table 4 , in combination with Table 2 which reports the results from our computational model for Germany. 23

\footnotetext{
${ }^{23} \mathrm{~A}$ more comprehensive table of results may be obtained upon request.
} 


\section{Conclusions}

Employment effects of an eastern EU enlargement are a big concern to politicians and the general public of present member countries, particularly now that membership negotiations have reached the highly controversial issue of labor movements. Existing studies of enlargement effects do not sufficiently accommodate this concern. The purpose of this paper was to provide a unified general equilibrium framework for investigating employment effects, alongside the trade integration effects and the costs of enlargement. Our contribution is twofold. First, we have derived key intuitive insights into how trade integration and immigration affect domestic labor markets. Our arguments rest on a stylized theoretical model that combines a search theoretic explanation of unemployment with capital accumulation and household dynamics. We have paid due attention to the fact that fiscal policy rules pertaining to unemployment and wage taxation are important in determining how enlargement can affect unemployment. And secondly, we have empirically implemented an enriched version of such a model by means of calibration techniques. Simulations of the model allowed to trace in quite some detail the potential effects of EU enlargement on the German economy. Finally, we introduced a method of extending our empirical results also to other EU15 countries.

We found, both theoretically and empirically, that the labor market effects of trade integration importantly depend on the fiscal policy rules relating to unemployment compensation and wage taxation. Our base case scenario keeps unemployment benefits and the wage tax allowance constant in real terms and thereby installs some degree of wage rigidity. Trade integration of the kind implied by EU enlargement is expansionary and, by raising the capital intensity of production, boosts the marginal productivity of labor. With constant unemployment benefits, job values increase by more than wages, leading firms to post more vacancies. As labor markets become tight, unemployment declines. In a situation where the economy suffers from excessive bargaining power of workers or is stuck with high unemployment benefits, resulting in high wages and unemployment, integration yields further welfare gains, over and above the traditional ones, by stimulating employment. We also found that the expansionary effects of enlargement in Germany yield a remarkable fiscal dividend that could be used to cut the wage tax, despite of the need to finance higher net contributions to the EU. This reinforces the reduction in the unemployment rate.

Our numerical model tells us that, in quantitative terms, the labor market effects of trade integration are rather modest compared to those of immigration. We look at a scenario, based on econometric projections of migration from CEECs to EU15 countries, which features a concentration of immigration of low-skilled labor. Our numerical results reveal that low-skilled workers will find both their wages and employment prospects directly impaired by an inflow of low-skilled workers, while the high-skilled gain on both accounts. Interestingly, the same does 
not hold true for immigration of high-skilled which is also included in our scenario, albeit on a lower level. Both types of labor experience a lower level of unemployment, while at the same time enjoying a higher wage rate. In addition to these direct labor market effects, we have also provided an empirical estimate of the so-called "immigration surplus" that is implied by projected migration flows.

Broadening our focus to the other EU15 countries, we have been able to highlight and to gauge empirically the conflict of interest between present member countries which one can sense also from policy discussions and the regular summits. Countries are different in all relevant dimensions: trade integration, the fiscal burden, and immigration. While it seems clear that enlargement as such is not endangered by such differences, an open discussion of these issues, based on likely numerical magnitudes as presented in this paper, should improve the prospects for a smooth management of the enlargement process.

\section{Appendix: An Analytical Perspective}

\section{A.1 The Model}

To state the intuition given in section 3 more rigorously, the appendix states the model in more detail and provides some analytical comparative static results. ${ }^{24}$ Since other aspects of the model have been analyzed in more detail in Keuschnigg and Kohler (1996a,b), we focus on the analysis of equilibrium search unemployment. In line with the empirical evidence by Davis and Haltiwanger (1992), a large part of the labor market literature emphasizes job creation and job destruction as a principal source of unemployment. The core theory along these lines are the models of search-unemployment pioneered by Diamond (1982), Pissarides (1990), Hosios (1990) and Mortensen and Pissarides (1994) [see Mortensen and Pissarides (1999) for a survey]. The trade literature has largely neglected the analysis of integration and search-generated unemployment. The few exceptions neglect the role of investment as a prime transmission channel through which integration can affect unemployment. ${ }^{25}$ This paper in fact argues that integration affects unemployment mainly by stimulating investment. It has proved difficult, however, to integrate the theory of search-unemployment with meaningful models of savings and investment. When individual unemployment spells are stochastic, agents become heterogeneous with

\footnotetext{
${ }^{24}$ See Heijdra and Keuschnigg (2000) for more details, including individual optimization and aggregation of the household sector, as well as an analysis of labor market efficiency.

${ }^{25}$ Matusz (1996), Davidson, Martin and Matusz (1999) and Jansen and Turrini (2000) discuss trade in search and efficiency wage models without capital.
} 
respect to their past unemployment and savings history. In the absence of a tractable aggregation procedure, an income pooling assumption is unavoidable. The literature on growth and unemployment [e.g. Aghion and Howitt (1994)] and on real business cycles [e.g. Andolfatto (1996), Merz (1999), Den Haan, Ramey and Watson (1997), and Shi and Wen (1997, 1999)] adopts such an assumption of perfect insurance and income pooling within the extended family.

\section{A.2 Households}

Individual Dynasties: We extend an overlapping generations (OLG) model pioneered by Blanchard (1985) by incorporating search-unemployment and immigration. At each instant of time, a large number of identical "families" or "dynasties" is born. A dynasty faces an age independent probability of extinction. The number of new dynasties is exactly matched by the number of deaths to keep the population constant. The population may increase as a result of immigration, however. A dynasty counts a mass one of members who pool income to insure against individual labor income risk, making household income non-stochastic. ${ }^{26}$ Members care only about the dynasty's welfare. Expected utility of a representative dynasty of vintage $v$ is

$$
\Lambda_{v, 0} \equiv \int_{0}^{\infty} \Phi\left(C_{v, t}\right) e^{-(\rho+\beta) t} d t, \quad \Phi^{\prime}>0>\Phi^{\prime \prime},
$$

where $\beta$ is the instantaneous probability of death, $\rho$ is the pure rate of time preference and $C_{v, t}$ is consumption of a composite good including domestic and foreign commodities. In maximizing life-time utility, dynasties optimally postpone consumption and save out of current income whenever the real interest exceeds the pure rate of time preference.

Average labor income reflects the dynasty's unemployment experience. Its individual members continuously switch between states of employment and unemployment, giving $L_{v, t}$ employed and $U_{v, t}$ unemployed, $U_{v, t}+L_{v, t}=1$ at each instant. Idiosyncratic shocks destroy a constant proportion of the pre-existing matches between firms and workers. Part of the employed loose their jobs while unemployed agents find employment. Given a matching rate $f_{t}$, equal to the fraction of unemployed individuals finding a job, an exogenous job destruction rate $s,{ }^{27}$ and defining $\dot{L}_{v, t} \equiv d L_{v, t} / d t$, the stock of employed agents follows $\dot{L}_{v, t} \equiv f_{t} U_{v, t}-s L_{v, t}$. Workers earn net wages $W_{t}^{*}$ while the unemployed collect benefits $B_{t}^{U}$,

$$
W_{\tau}^{*} \equiv\left(1-t^{L}\right) W_{\tau}+B_{\tau}^{L}>B_{t}^{U}
$$

\footnotetext{
${ }^{26}$ See Andolfatto (1996), Merz (1999), Galí (1996), Den Haan et al.(1997), and Shi and Wen (1997,1999).

${ }^{27}$ At the cost of further complexity, we could make the job destruction rate endogenous as in Mortensen and Pissarides $(1994,1999)$. While none of the qualitative results hinge on this, the effects on unemployment would be magnified, see also Jansen and Turrini (2000).
} 
where $W_{t}$ is the gross real wage and $t^{L}$ is the marginal wage tax rate. The wage tax is indirectly progressive on account of a basic tax credit of $B_{t}^{L}$. An employed agent runs up a tax liability of $t^{L} W_{t}-B_{t}^{L}$. Since unemployed members receive benefits smaller than net wages, they erode the dynasty's average labor income and are, therefore, sent to search for a job. The asset values of employed and unemployed members, $v_{t}^{L}$ and $v_{t}^{U}$, reflect expected future income and are defined by the no-arbitrage conditions

$$
\begin{aligned}
& \text { (a) } \quad(r+\beta) v_{t}^{L}=W_{t}^{*}-s\left(v_{t}^{L}-v_{t}^{U}\right)+\dot{v}_{t}^{L}, \\
& \text { (b) } \quad(r+\beta) v_{t}^{U}=B_{t}^{U}+f_{t}\left(v_{t}^{L}-v_{t}^{U}\right)+\dot{v}_{t}^{U} .
\end{aligned}
$$

The real interest rate $r$ is constant throughout this section and $r+\beta$ denotes the risk adjusted discount rate of households. The valuation of an employed agent corresponds to the present value of the 'job dividend' including the net wage $W^{*}$ plus the expected capital gains $\dot{v}_{t}^{L}$ of remaining employed minus the expected capital loss $\left(v_{t}^{L}-v_{t}^{U}\right) s$ of loosing the job. The average human wealth of the dynasty is $H_{v, t}=L_{v, t} v_{t}^{L}+U_{v, t} v_{t}^{U}$. Higher unemployment subtracts from average human wealth. The dynasty thus attaches a differential value $v_{t}^{L}-v_{t}^{U}$ to an additional member switching from search to employment. The job dividend reflects the excess of the aftertax wage $W^{*}$ over the reservation wage $W_{t}^{R} \equiv B_{t}^{U}+f_{t}\left(v_{t}^{L}-v_{t}^{U}\right)$ which is the unemployment benefit plus the expected gain from finding employment somewhere else.

Aggregate Household Sector: At each instant, a number $N_{t, t}$ of new dynasties arrive while mortality eliminates a fraction $\beta$ of them. The population thus evolves as $\dot{N}_{t}=N_{t, t}-\beta N_{t}$. With constant population, births must balance with deaths, $N_{t, t}=\beta N_{t}$. Frequencies and probabilities coincide when numbers are large. Since mortality is constant among all groups, the cohort size of generation $v$ at time $t$ is $N_{v, t} \equiv N_{v, v} e^{\beta(v-t)}(t \geq v)$. Adding up gives a total population of $N_{t} \equiv \int_{-\infty}^{t} N_{v, t} d v$. Assuming that new dynasties are born bare of any assets $\left(A_{t, t}=0\right)$, we first aggregate individual savings, ${ }^{28}$

$$
\dot{A}_{t} \equiv r A_{t}+W_{t}^{*} L_{t}+B_{t}^{U} U_{t}+T_{t} N_{t}-C_{t},
$$

where $T_{t}$ is a lump-sum transfer per capita, or tax if it is negative. These variables are defined in real terms, i.e. in units of the composite good.

Assuming that new dynasties start life without jobs $\left(U_{t, t}=1\right.$ and $\left.L_{t, t}=0\right)$, individual job

\footnotetext{
${ }^{28}$ Individual and aggregate variables are linked as $x_{t} \equiv \int_{-\infty}^{t} x_{v, t} N_{v, v} e^{\beta(v-t)} d v$. Note that individual savings earn an annuity rate of interest $r+\beta$ which reflects the existence of a reverse life-insurance, paying a premium $\beta A$ during life-time but collecting the remaining assets upon death. From an aggregate perspective, this simply reflects a transfer of wealth upon death of old agents to currently living generations and thus cancels.
} 
accumulation implies aggregate labor market flows

$$
\dot{L}_{t}=f_{t} U_{t}-(s+\beta) L_{t}, \quad \dot{U}_{t}=N_{t, t}+s L_{t}-\left(f_{t}+\beta\right) U_{t} .
$$

Using $L_{t}+U_{t}=N_{t}$ and $\dot{N}_{t}=N_{t, t}-\beta N_{t}$, unemployment dynamics just mirrors the evolution of employment. Employment expands as unemployed workers find jobs, and it falls either because jobs are destroyed (at rate $s$ ) or workers die (at rate $\beta$ ). The flow into unemployment results from the arrival of new dynasties and the destruction of existing jobs, whereas the flow out of unemployment consists of workers finding a job or dying. Without loss of generality, we may assume that population size is unity prior to an immigration shock $\left(N_{t}=1\right)$. In the absence of migration, levels and rates of (un-)employment thus coincide.

\section{A.3 Firms}

Investment Firms: Production rests on two types of firms. Investment firms accumulate physical capital while production firms use labor and rent capital services to produce goods. The investment firm purchases $I_{t}$ units of the composite good and builds up a stock of capital $K_{t}$ subject to $\dot{K}_{t}=I_{t}-\delta K_{t}$, where $\delta$ is the depreciation rate. The firm's objective is the present value of cash flows $\left(1-t^{K}\right) R_{t} K_{t}-I_{t}$ where $t^{K}$ is a source based tax on capital income and $R_{t}$ is the real rental rate, measured in units of the composite good. In equilibrium, investment equates the marginal value product net of taxes with the user cost of capital:

$$
\left(1-t^{K}\right) R_{t}=r+\delta
$$

Production Firms: Following Pissarides (2000), we assume firms to be large enough so that employment risk washes out over the firm's total labor force even though hiring of and separation from individual workers is stochastic. The firm loses a proportion of its workforce either due to idiosyncratic shocks or death of agents. To augment its labor force, it must post vacancies $V$,

$$
\dot{L}_{t}=q_{t} V_{t}-(s+\beta) L_{t}
$$

where $q_{t}$ is the instantaneous probability of successful hiring. Each vacancy requires a labor input of $\kappa$ for search activities. To find new workers, the firm must thus divert part of its workforce to search and recruitment activities. Using a linearly homogeneous production technology, the representative firm produces a quantity $Y$ of goods from capital $K$ and labor $L^{D}$ :

$$
Y_{t}=F\left(K_{t}, L_{t}^{D}\right), \quad L_{t}^{D}=L_{t}-\kappa V_{t}
$$

The firm's real cash flow is $\left(1-t^{K}\right)\left(p^{h} Y / P-R K-W L\right)$. The firm chooses time paths for output, capital, vacancies and employment in order to maximize the present value of its cash 
flow subject to (A.7-8), taking as given its initial labor force. Optimal firm behavior is

$$
\begin{aligned}
\text { (a) } R_{t} & =p_{t}^{h} F_{K} / P_{t} \\
\text { (b) } \mu_{t}^{L} q_{t} & =\kappa \cdot\left(1-t^{K}\right) p_{t}^{h} F_{L} / P_{t} \\
\text { (c) } \mu_{t}^{L} & =\int_{t}^{\infty}\left(1-t^{K}\right)\left(p_{\tau}^{h} F_{L} / P_{\tau}-W_{\tau}\right) e^{-(r+\beta+s)(\tau-t)} d \tau .
\end{aligned}
$$

Capital is rented until its marginal value product is equal to its rental rate. According to (A9.b), the firm posts new vacancies until the marginal cost of recruitment in terms of foregone output equals the expected value of a vacancy. The value of a filled job in (A9.c) is the expected present value of the rent which the firm earns on that job. The instantaneous discount rate reflects the risk of job termination due to death, $\beta$, and separation for other reasons, $s$.

\section{A.4 Wage Bargaining}

Vacancies and workers on job search participate in an anonymous matching process. The number of matches $X_{t}$ at each instant of time is a function of the number of agents searching on both sides of the market, specified as $X_{t}=x_{0} U_{t}^{\epsilon} V_{t}^{1-\epsilon}$. The fraction of unemployed agents finding a job is $f\left(\theta_{t}\right) \equiv X_{t} / U_{t}$, and the fraction of vacancies filled is $q\left(\theta_{t}\right) \equiv X_{t} / V_{t}$ where $\theta_{t} \equiv V_{t} / U_{t}$ is labor market tightness. The transition rates satisfy

$$
f\left(\theta_{t}\right)=\theta_{t} q\left(\theta_{t}\right), \quad f^{\prime}\left(\theta_{t}\right)>0>f^{\prime \prime}\left(\theta_{t}\right), \quad q^{\prime}\left(\theta_{t}\right)<0<q^{\prime \prime}\left(\theta_{t}\right) .
$$

Given the specification of the matching function, the elasticities $\epsilon \equiv-\theta q^{\prime}(\theta) / q(\theta)$ and $1-\epsilon=$ $\theta f^{\prime}(\theta) / f(\theta)$ are constant and lie in the unit interval.

Following Pissarides (2000), we assume that the two parties share the job rent created by a new match according to the generalized Nash bargaining solution. When they agree on a higher wage, the job value to the worker as implied by (A.3), $v_{t}^{L}-v_{t}^{U}$, rises while the job value to the firm (A9.c) falls. The $i$-th worker-firm pair divides the job surplus by agreeing on a wage $W_{t}=\arg \max \left[v_{t}^{L}(i)-v_{t}^{U}(i)\right]^{\zeta}\left[\mu_{t}^{L}(i)\right]^{1-\zeta}$, where $\zeta$ and $1-\zeta$ are the bargaining weights of workers and firms. The bargaining solution satisfies $\zeta\left(1-t^{L}\right) \mu_{t}^{L}=(1-\zeta)\left(1-t^{K}\right)\left(v_{t}^{L}-v_{t}^{U}\right)$ and results in a net wage $\left(1-t^{L}\right) W_{t}=\zeta\left(1-t^{L}\right) p_{t}^{h} F_{L} / P_{t}+(1-\zeta)\left(B_{t}^{U}+f_{t}\left(v_{t}^{L}-v_{t}^{U}\right)-B_{t}^{L}\right)$. The wage is a weighted average of the job surplus net of the wage tax and the worker's reservation rate [less the employment subsidy]. The reservation rate is the unemployment benefit plus the expected gain from finding a job elsewhere. With a larger bargaining power, the worker appropriates more of the surplus. Using the bargaining solution again, we obtain:

$$
W_{t}=\zeta \cdot \frac{p_{t}^{h} F_{L}}{P_{t}}+(1-\zeta) \cdot \frac{B_{t}^{U}-B_{t}^{L}}{1-t^{L}}+\zeta \cdot \frac{f_{t} \mu_{t}^{L}}{1-t^{K}} .
$$




\section{A.5 Equilibrium}

In the absence of public debt, the government budget identity is given by:

$$
T_{t} N_{t}+B_{t}^{U} U_{t}+T_{t}^{E}=\left(t^{L} W_{t}-B_{t}^{L}\right) L_{t}+t^{K}\left(p_{t}^{h} Y_{t} / P_{t}-W_{t} L_{t}\right),
$$

where $T^{E}$ represents net contributions to the European Union (EU). Revenues stem from a dual (capital and labor) income tax, and are spent on unemployment benefits, transfers to the household sector and net EU contributions. ${ }^{29}$

Savings are invested in three perfectly substitutable assets, i.e. shares of production and investment firms as well as net foreign assets $A^{F}$. Equilibrium requires that household sector wealth equals the real value of all outstanding assets. From the corresponding flow identities, we obtain the current account

$$
\dot{A}_{t}^{F}=r A_{t}^{F}+\left(p_{t}^{h} Y_{t} / P_{t}-C_{t}-I_{t}\right)-T_{t}^{E}
$$

The term in brackets is the trade balance which is domestic real income less absorption. Replacing $I$ by $\dot{K}+\delta K$ and integrating by parts, we can derive the present value of consumption, $\int_{0}^{\infty} C_{t} e^{-r t} d t=A_{0}^{F}+K_{0}+\Lambda^{*}$, where

$$
\Lambda^{*} \equiv \int_{0}^{\infty}\left[\left(1-t^{E}\right) p_{t}^{h} Y_{t} / P_{t}-(r+\delta) K_{t}\right] e^{-r t} d t
$$

Net contributions, in real terms, amount to $T^{E}=t^{E} p^{h} Y / P$ where $t^{E}$ is the net contribution rate. Given a constant real interest rate, and ignoring issues of intergenerational redistribution, we can take the present value of domestic consumption as our aggregate welfare measure. Welfare changes along with $\Lambda^{*}$ since $K_{0}+A_{0}^{F}$ is predetermined.

\section{A.6 Comparative Statics}

Capital Intensity: Removing trade barriers squeezes import prices $p^{m}=(1+\tau) \bar{p}^{m}$ and thereby favorably affect the price index. Indicating percentage changes by a hat, $\hat{p}^{h}=d p^{h} / p^{h}$, $\hat{\tau}=d \tau /(1+\tau)$, trade costs and output prices feed into the price index as

$$
\hat{P}=(1-\gamma) \hat{p}^{h}+\gamma \hat{\tau}
$$

where $\gamma$ is the import share of domestic absorption. We use $R^{K} \equiv\left(1-t^{K}\right) p^{h} F_{K} / P$ and $R^{L} \equiv\left(1-t^{K}\right) p^{h} F_{L} / P$ to denote real rental rates net of taxes. By (A.6) and (A.9a), $R^{K}=$

\footnotetext{
${ }^{29}$ The simulation model also includes tariff revenues plus more taxes, spending items and public debt.
} 
$r+\delta$. Investment incentives are strengthened on two fronts: higher prices of home goods $p^{h}$ and lower import barriers. The capital labor ratio $k=K /(L-\kappa v)$ thus increases by ${ }^{30}$ $\hat{k}=\left(\hat{p}^{h}-\hat{\tau}\right) \gamma \sigma^{K} /(1-\alpha)$. The net real job surplus, in turn, increases along with higher capital intensity:

$$
\hat{R}^{L}=\hat{p}^{h}+\hat{F}_{L}-\hat{P}=\left(\hat{p}^{h}-\hat{\tau}\right) \gamma /(1-\alpha)
$$

Labor Market Tightness: With the capital labor ratio and, thus, the net rental price of labor fixed, the wage equation (A.11), the free entry condition (A.9b) and the asset price equation (A.9c) solve for the value of a filled job $\mu^{L}$, the labor market tightness $\theta$, and the wage rate $W$ independently of the levels of employment and capital. This implies that the asset price instantaneously jumps to its stationary value, implying $\dot{\mu}^{L}=0$ at all dates. We can state ${ }^{31}$

Proposition 1 Labor market tightness increases when unemployment benefits $B^{U}$ and tax allowance $B^{L}$ are kept constant in real terms, with $B^{U}>B^{L}$.

Proof. The asset price capitalizes net producer rents according to the stationary version of (A.9c), $(r+\beta+s) \mu^{L}=R^{L}-\left(1-t^{Y}\right) W$. Substituting the wage equation in (A.11), $\left(1-t^{Y}\right) W=\zeta R^{L}+(1-\zeta)\left(B^{U}-B^{L}\right)+f \zeta \mu^{L}$, yields

$$
[r+\beta+s+\zeta f(\theta)] \mu^{L}=(1-\zeta)\left(R^{L}+B^{L}-B^{U}\right) .
$$

This and (A.9b), $\mu^{L} q(\theta)=\kappa R^{L}$, simultaneously determine $\theta$ and $\mu^{L}$. Log-linearization yields $(r+\beta+s+\zeta f) \mu^{L} \hat{\mu}^{L}+\zeta \mu^{L} f \hat{f}=(1-\zeta) R^{L} \hat{R}^{L}$. Use (a) to obtain

$$
(r+\beta+s+\zeta f) \mu^{L}\left(\hat{\mu}^{L}-\hat{R}^{L}\right)+\zeta \mu^{L} f \hat{f}=(1-\zeta)\left(B^{U}-B^{L}\right) \hat{R}^{L} .
$$

With $\hat{f}=(1-\epsilon) \hat{\theta}$ from (A.10) and $\hat{\mu}^{L}-\hat{R}^{L}=\epsilon \hat{\theta}$ from (A.9b), we have

$$
\hat{\theta}=\frac{(1-\zeta)\left(B^{U}-B^{L}\right)}{[(r+\beta+s) \epsilon+\zeta f] \mu^{L}} \hat{R}^{L} .
$$

Labor market tightness increases with a higher rental price $R^{L}$ as in (A.16).

We emphasize the case of constant real benefits $B^{L}$ and $B^{U}$. Heijdra and Keuschnigg (2000) show, however, that labor market equilibrium depends on the specific fiscal policy rules in place.

\footnotetext{
${ }^{30}$ The elasticity of substitution in production is $\sigma^{K}=-(1-\alpha) f^{\prime} /\left(k f^{\prime \prime}\right)$ and capital's share in value added is $\alpha=k f^{\prime} / f$ where $f(k)$ denotes the production function in intensive form.

${ }^{31}$ From now on, we restrict ourselves, for reasons of simplicity only, to a common marginal tax rate $t^{L}=t^{K}=t^{Y}$. We continue to assume that the basic tax allowance applies only to wage income.
} 
Fiscal policy is important because it affects wage formation which determines producer rents and incentives to post vacancies. If benefits were indexed to net wages, $B^{U}=b^{U}\left(1-t^{Y}\right) W$ and $B^{L}=b^{L}\left(1-t^{Y}\right) W$, net wages, producer rents and asset price of filled jobs would all increase proportionately. As the expected value of posting a vacancy would rise by the same amount as the firm's search cost, there would be no reason to revise recruitment. Another case is progressive wage taxation with unemployment benefits indexed, $B^{U}=b^{U}\left(1-t^{Y}\right) W$, but real tax allowance $B^{L}$ constant. In this case, wages would increase relatively more than rental costs, leave smaller producer rents, and contribute to weaker market tightness.

Employment Dynamics: Unemployment falls when labor markets become tighter. While $\theta$ jumps instantaneously to its steady state value, the reduction in unemployment is gradual as in (A.5) with an adjustment speed equal to $\beta+s+f$. Log-linearization yields

$$
\dot{\hat{U}}_{t}=-(1-\epsilon) f \cdot \hat{\theta}-(\beta+s+f) \hat{U}_{t}
$$

where $\hat{U} \equiv d U / U$ and $\dot{\hat{U}} \equiv d \dot{U} / U$. Starting with $\hat{U}_{0}=0$ and noting $\hat{\theta}$ from (A.17), the transitional solution is:

$$
\hat{U}_{t}=\hat{U}_{\infty}\left[1-e^{-(\beta+s+f) t}\right], \quad \hat{U}_{\infty}=-\frac{(1-\epsilon) f}{\beta+s+f} \hat{\theta} .
$$

Since the vacancy ratio jumps up instantaneously, labor use in production, $L^{D}=L-\kappa V$, first declines and picks up only afterwards as firms build up their labor force. Taking the solution for the unemployment rate, the short- and long-run effects are

$$
\hat{L}_{0}^{D}=-\frac{\kappa \theta U}{L^{D}} \cdot \hat{\theta}<0, \quad \hat{L}_{\infty}^{D}=\frac{U}{L^{D}} \cdot \frac{\chi}{\beta+s+f} \cdot \hat{\theta},
$$

where $\chi \equiv(1+\kappa \theta)(1-\epsilon) f-\kappa \theta(\beta+s+f)$. Employment in production thus follows

$$
\hat{L}_{t}^{D}=\hat{L}_{\infty}^{D}-\left(\hat{L}_{\infty}^{D}-\hat{L}_{0}^{D}\right) e^{-(\beta+s+f) t}
$$

With productive employment determined and the effect on the capital labor ratio noted prior to (A.16), we derive an output response

$$
\hat{Y}=\hat{L}^{D}+\alpha \hat{k}, \quad \hat{k}=\frac{\gamma \sigma^{K}}{1-\alpha} \cdot\left(\hat{p}^{h}-\hat{\tau}\right)>0 .
$$

Productive employment first falls as firms allocate more labor to recruitment activities. Since the capital labor ratio picks up instantaneously, the output response is ambiguous in the short-run. 
Welfare: We report the change in welfare, based on the welfare measure given in (A.14), as an annuitized flow in percent of real GNP, $\hat{\Lambda}^{*} \equiv \frac{r \cdot d \Lambda^{*}}{\left(1-t^{E}\right) p^{h} Y / P}=r \int_{0}^{\infty} \hat{Y}_{t}^{C} e^{-r t} d t$ with

$$
\hat{Y}_{t}^{C}=\hat{p}_{t}^{h}-\hat{P}_{t}-\hat{t}^{E}+(1-\alpha) \hat{L}_{t}^{D}+\left[F_{K}-\frac{(r+\delta) P}{\left(1-t^{E}\right) p^{h}}\right] \frac{K}{Y} \hat{K}_{t}
$$

Since recruitment absorbs part of the labor force, employment in production is only $L^{D}=L-\kappa V$ and changes according to $\hat{L}_{t}^{D}=-\left[(1+\kappa \theta) \hat{U}_{t}+\kappa \theta \hat{\theta}\right] U / L^{D}$. Using (A.6) together with (A.9a) and (A.15), we obtain

$$
\hat{\Lambda}^{*}=\gamma\left(\hat{p}^{h}-\hat{\tau}\right)-\hat{t}^{E}+r \int_{0}^{\infty}\left[(1-\alpha) \hat{L}_{t}^{D}+\frac{t^{K}-t^{E}}{1-t^{E}} \alpha \hat{K}_{t}\right] e^{-r t} d t,
$$

where $\hat{t}^{E}=t^{E} /\left(1-t^{E}\right)$ defines the relative change in the net contribution rate. The expression captures the major sources of the gains from integration: First, welfare improves upon better terms of trade and lower real trade costs. ${ }^{32}$ Second, the home country directly loses from a higher net contribution rate to the EU budget. Third, welfare potentially improves upon more employment being allocated to production. And fourth, the country gains from induced investment to the extent that it is suppressed initially by a distorting capital income tax. ${ }^{33}$ Note that, for any given capital labor ratio, investment must pick up to accommodate employment gains, $\hat{K}_{t}=\hat{k}+\hat{L}_{t}^{D}$. With respect to the welfare implications of labor market tightness, we state

Proposition 2 Welfare increases with labor market tightness if (a) the workers' bargaining power exceeds the elasticity of matching with respect to job searchers, $\zeta>\epsilon$, and (b) unemployment benefits exceed the employment subsidy, $B^{U}>B^{L}$.

Proof. Labor market tightness affects welfare in (A.24). By (A.20-21), we calculate

$$
r \int_{0}^{\infty} \hat{L}_{t}^{D} e^{-r t} d t=\hat{L}_{\infty}^{D}-\frac{r\left(\hat{L}_{\infty}^{D}-\hat{L}_{0}^{D}\right)}{r+\beta+s+f}=\frac{U}{L^{D}} \frac{[\chi-r \kappa \theta]}{r+\beta+s+f} \hat{\theta} .
$$

Divide (a) in proposition 1 by $R^{L}$, use $\mu^{L} q=\kappa R^{L}$ from (A.9b) and multiply by $f=\theta q$ to get $(r+\beta+s) \kappa \theta+\zeta \kappa \theta f=(1-\zeta) f-(1-\zeta) f \cdot\left(B^{U}-B^{L}\right) / R^{L}$. Using this and the definition of $\chi$ in (A.20) to replace the square bracket in (A.25), and get

$$
r \int_{0}^{\infty} \hat{L}_{t}^{D} e^{-r t} d t=\frac{(\zeta-\epsilon)(1+\kappa \theta) f(\theta)+(1-\zeta) f(\theta)\left(B^{U}-B^{L}\right) / R^{L}}{r+\beta+s+f} \cdot \frac{U}{L^{D}} \hat{\theta}
$$

\footnotetext{
${ }^{32}$ The simulation model also captures the loss in tariff revenue that results from the Europe agreements.

${ }^{33}$ The simulation model allows for monopolistic competition and markup pricing of specialized capital goods. For this reason, capital accumulation is too low from a social perspective, and investment stimulation yields first order welfare gains even without tax distortions.
} 
which shows the conditions for welfare gains to be positive.

Although tighter labor markets raise welfare on account of lower unemployment, they also lead to welfare losses by raising firms' search-costs, making the net welfare effects ambiguous. Hosios (1990) has shown that equilibrium search-unemployment is efficient in a an economy without government activity $\left(B^{U}=B^{L}=0\right)$ if $\zeta=\epsilon$. In this case, a policy induced increase in labor market tightness has zero first order welfare effects. If the bargaining power of workers exceeds the matching elasticity, bargaining results in too high wages, insufficient job creation and, consequently, excessive unemployment. Unemployment benefits further exacerbate the problem since they also boost wages and retard job creation. Under these circumstances, any shock that stimulates employment promises first order welfare gains.

Immigration: We consider two immigration scenarios. In this subsection we confine to the stock scenario and assume that immigration augments all age cohorts by the same factor such that the total population $N_{t} \equiv \int_{-\infty}^{t} N_{v, t} d v$ remains stationary. At each instant, a number of new agents $N_{t, t}=\beta N_{t}$ arrives that keeps total population constant. There are now transitional effects on the demographic structure. In an alternative flow scenario, location choice is restricted to new agents implying that immigration is concentrated among the young only. A permanently larger share of newborns worldwide locate in the home country while old agents remain locked in their country of birth. Thus, the number $N_{t, t}$ of new arrivals or young workers in present EU member countries is permanently higher and leads to a gradual increase in the domestic population by $\dot{N}_{t}=N_{t, t}-\beta N_{t}$ until the stock converges to $N=N_{t, t} / \beta$. There will be longlasting transitional effects on aggregate labor supply. The simulation section will compare the transitional effects of the two scenarios. In all cases, we assume that migrants arrive bare of any financial assets.

In the small open economy, the capital labor ratio depends exclusively on real interest and prices as fixed on international markets. Factor rentals thus remain constant and wage formation is not disturbed. According to (A.17), immigration does not affect labor market tightness. The increased population splits between employed and unemployed agents, $N=L+U$. According to (A.5), the number of unemployed converges to $U=N(\beta+s) /(\beta+s+f)$, leaving the longrun unemployment rate $U / N$ unaffected. Immigration increases the number of employed and unemployed agents, the number of vacancies, labor input in production, capital stock and output all proportionately without effect on the capital-labor and vacancy-unemployment ratios. With the stock scenario of immigration, the number of new and old workers increases in proportion, keeping the age structure constant. Immigration nevertheless holds important transitional effects on labor markets since the $d N$ migrants find work only after a search period. With $L_{0}$ being predetermined, immigration thus raises the number of job searchers instantaneously by $d U_{0}=$ 
$d N$, implying $\hat{U}_{0}=\hat{N} / U$ and a short-run overshooting of the unemployment rate of $\hat{U}_{0}-\hat{N}=$ $\hat{N}(1-U) / U$.

These arguments miss out on a basic channel that works to reduce unemployment. The simulation model features a monopolistically competitive production sector with product differentiation due to free entry of specialized firms. As immigration swells the labor force and induces investment to keep capital intensity constant, output expands proportionately, at least in the long-run. With the scale of individual firms fixed, output comes in the form of additional product varieties giving rise to increasing returns due to specialization. The variety effect reduces the price index for the composite capital good which raises capital intensity and the rental rate of labor. If unemployment benefits are kept constant in real terms, labor market tightness increases and unemployment falls.

Proposition 3 In a small open economy, immigration does not affect the capital labor and vacancy unemployment ratios. It raises short-run unemployment but leaves the long-run unemployment rate unaffected. If production is subject to increasing returns due to specialization, the output gains from immigration boost investment and labor rentals and thereby reduce long-run unemployment rates if real benefits are kept constant.

\section{A.7 The Computational Model}

Further Details of the Model: This paper differs from Keuschnigg and Kohler (1996, 2002) by allowing for search unemployment but shares other model elements. We repeat only the most important features that add to the core elements introduced in this appendix. Production occurs in twelve sectors that are connected by interindustry shipments of intermediate goods. Free entry subject to a zero profit condition determines the equilibrium number of firms and differentiated goods within each sector, giving rise to increasing returns due to specialization. Demand stems from Dixit-Stiglitz (1977) preferences, i.e. different brands are imperfectly substitutable. The composition of investment, government and export demand similarly reflects allocation of expenditure across differentiated, sectoral commodities. On the supply side, investment is subject to installation costs, making transitional dynamics more realistic. Employment and capital stocks are accumulated separately in each sector. Labor supply and demand distinguish high and low skilled labor with job matching taking place in two segmented markets.

The model is calibrated to 1996 benchmark data of the German economy. We select certain taste and technology parameters from the econometrics literature and also draw on parameters commonly used in the real business cycle literature [see Andolfatto (1996), Burda and Weder (1998), Mortensen and Pissarides (1999) etc.]. Other parameters are calibrated such that the stationary solution reproduces the benchmark data set. The model is implemented quarterly to 
get meaningful lengths of unemployment spells. In the stationary state, unemployment rates of high and low skilled workers are set at 6 and 10 percent, respectively. Unemployment benefits amount to 70 percent of net wages. The bargaining power $\zeta$ is set at .5 for both skill types, and the matching elasticity $\epsilon$ with respect to the unemployed at .4 [see Broersma and Van Ours (1999) for a survey]. In line with the empirical literature on search-unemployment, and drawing on German evidence by Schmidt (1999), we set the transition rates such that average unemployment duration $1 / f$ of high (low) skilled labor is 1.75 (3) quarters. Vacancy duration $1 / q$ is 1.4 (1.3) quarters. Together with a quarterly mortality rate of $\beta=1 / 60,{ }^{34}$ these values then imply a quarterly split rate $s$ to replicate the labor market equilibrium. The calibrated value implies a job duration of about 27 quarters for both skill types. Calibration generates a search-coefficient $\kappa$ such that roughly two (three) percent of the skilled (unskilled) labor force is absorbed in recruitment. Calibration of the rest of the model is standard and not repeated.

\section{A.8 Migration Scenario}

The data underlying our migration scenario are taken from projections presented by the European Integration Consortium (EIC) (2001). These are based on a time-series model which explains the change in the stock of foreign residents relative to the home population by changes in German wages relative to foreign wages, as well as changes in the unemployment rates in Germany and the foreign country, respectively. The model allows projections for the number of people from CEECs10 living in Germany in the years up to 2030. These projections have then been extended to other EU15-countries, based on how the migrants from the CEECs10 that have lived in the EU15 in 1998 were distributed across EU15-countries. Extrapolation leads to an estimated increase in the number or CEECs10 migrants living in the EU15, from some 850 thousand in 1998 to roughly 3.9 Mio people in 2030 (EIC, Part A, Table 7.11). The corresponding numbers for Germany are 550 thousand and 2.5 Mio, respectively. We take differences in estimated stocks to obtain net migration flows and follow EIC in assuming that 35 percent of that flow will enter the labor market (EIC, p. 101). Since our model distinguishes between skilled and unskilled labor, we have to do the same with migration inflows. Evidence produced by EIC (Part A, Table 5.6) indicates that roughly 40 percent of the people from CEECs employed in the EU in 1995 had a formal education level corresponding to secondary education (2nd stage), or higher. We therefore assume that 40 percent of the people migrating from east to west will fall into our category of skilled labor. This gives us two separate flows of migrants

\footnotetext{
${ }^{34}$ An expected life-time of 15 years or 60 quarters may seem rather low. This parameter is not to be interpreted literally, however, since it applies equally to both young and old generations. It rather reflects disconnectedness of dynasties and discounting of future wage incomes.
} 
entering EU15-countries' labor markets for skilled and unskilled labor. In a last step, we relate these inflows to the initial stocks which we calculate using labor force data from EIC (Part A, Table 3.2), and an index of formal schooling for each EU15-country. More specifically, $L^{j}$ is the labor force of EU15-country $j$ and $S^{j}$ is that country's formal schooling index. Then country $j$ 's unskilled labor force is calculated as $L^{j} \times\left(S^{G} / S^{j}\right) / u^{G}$, where $u^{G}$ is the the ratio of unskilled labor in the calibrated German CGE model. ${ }^{35}$ The resulting rate of increase in the German labor force is 6.15 percent for unskilled and 0.84 percent of skilled labor, respectively.

\section{References}

[1] Anderson, Kym and Rod Tyers (1995), Implications of EU Expansion for European Agricultural Policies, Trade and Welfare, in: Baldwin, R.E., P. Haaparanta and J. Kiander (eds.), Expanding Membership of the European Union, Cambridge: Cambridge University Press, 209-237.

[2] Aghion, Philippe and Peter Howitt (1994), Growth and Unemployment, Review of Economic Studies 61, 477-494.

[3] Andolfatto, David (1996), Business Cycles and Labour-market Search, American Economic Review 86, 112-132.

[4] Baldwin, Richard E., Joseph F. Francois and Richard Portes (1997), The Costs and Benefits of Eastern Enlargement: The Impact on the EU and Central Europe, Economic Policy, 127176 .

[5] Baldwin, Richard E. and Elena Seghezza (1998), Regional Integration and Growth in Developing Nations, Journal of Economic Integration 13, 367-399.

[6] Blanchard, Olivier (1985), Debt, Deficits, and Finite Horizons, Journal of Political Economy 93, 223-247.

[7] Breuss, Fritz (1995), Costs and Benefits of EU's Eastern Enlargement, Yriö Jahnsson European Integration Lectures, Helsinki.

[8] Broersma, Lourens and Jan C. Van Ours (1999), Job Searchers, Job Matches and the Elasticity of Matching, Labour Economics 6, 77-93.

[9] Burda, Michael C. and Mark Weder (1998), Endogenes Wachstum, gleichgewichtige Arbeitslosigkeit und persistente Konjunkturzyklen, Humboldt University of Berlin, Discussion Paper.

\footnotetext{
${ }^{35}$ This procedure simply takes $1 / S^{j}$ to scale $u^{G}$ up or down to arrive at $u^{j} . S^{j}$ is calculated as the weighted sum of gross school enrollment rates, with weights equal to $0.1,0.4$ and 0.5 , respectively, for primary, secondary and tertiary education. The data are from the Worldbank Development indicators 2001 (source: www.worldbank.org).
} 
[10] Davidson, Carl, Lawrence Martin and Steven Matusz (1999), Trade and Search Generated Unemployment, Journal of International Economics 48, 271-299.

[11] Davis, Donald R. (1998a), Technology, Unemployment, and Relative Wages in a Global Economy, European Economic Review 42, 1613-1633.

[12] Davis, Donald R. (1998b), Does European Unemployment Prop Up American Wages? National Labor Markets and Global Trade, American Economic Review 88, 478-494.

[13] Davis, S.J. and J. Haltiwanger (1992), Gross Job Creation, Gross Job Destruction, and Employment Reallocation, Quarterly Journal of Economics 107, 819-864.

[14] De New, John P. and Klaus F. Zimmermann (1999), Wage and Mobility Effects of Trade and Migration, in: Mathias Dewatripont, Andre Sapir and Khalid Sekkat (eds.), Trade and Jobs in Europe: Much Ado about Nothing?, Oxford: Oxford University Press, 139-160.

[15] Den Haan, Wouter J., Garey Ramey and Joel Watson (1997), Job destruction and propagation of shocks, University of California, San Diego, Discussion Paper 97-23.

[16] Diamond, Peter A. (1982), Aggregate demand management in search equilibrium, Journal of Political Economy 90, 881-894.

[17] Dixit, Avinash and Joseph E. Stiglitz (1977), Monopolistic Competition and Optimum Product Diversity, American Economic Review 67, 297-308.

[18] ECOFIN (2001), The Economic Impact of Enlargement, Directorate Generale for Economic and Financial Affairs: Enlargement Papers No. 4.

[19] European Commission (1997), Agenda 2000, Luxembourg.

[20] European Commission (2002), Communication from the Commission: Information Note Common Financial Framework 2004-2006 for the Accession Negotiations, Brussels, 2002.

[21] European Council (1999), Presidency Conclusions - Berlin European Council, 24 and 25 March 1999, Berlin, 1999.

[22] European Integration Consortium: DIW, CEPR, FIEF, IAS, IGIER (2001), The Impact of Eastern Enlargement on Employment and Labour Markets in the EU Member States, Study on behalf of the Employment and Social Affairs Directorate General of the European Commission, Berlin and Milano.

[23] Finger, Michael J., Merlinda D. Ingco and Ulrich Reincke (1996), The Uruguay Round: Statistics on Tariff Concessions Given and Received: Washington D.C.: The World Bank.

[24] Gali, Jordi (1996), Unemployment in dynamic general equilibrium models, European Economic Review 40, 839-845.

[25] Heijdra, Ben J. and Christian Keuschnigg (2000), Integration and Search Unemployment: An Analysis of Eastern EU Enlargement, CESifo WP 341, Munich.

[26] Hosios, A.J. (1990), On the efficiency of matching and related models of search and unemployment, Review of Economic Studies 57, 279-298. 
[27] Jansen, Marion and Alessandro Turrini (2000), Job Creation, Job Destruction, and the International Division of Labour, Discussion Paper No. 2472, CEPR, London.

[28] Keuschnigg, Christian (1998), Investment Externalities and a Corrective Subsidy, International Tax and Public Finance 5, 449-469.

[29] Keuschnigg, Christian and Wilhelm Kohler (1996a), Commercial Policy and Dynamic Adjustment Under Monopolistic Competition, Journal of International Economics, 40, 373410.

[30] Keuschnigg, Christian and Wilhelm Kohler (1996b), Austria in the European Union: dynamic gains from integration and distributional implications, Economic Policy, 157-211.

[31] Keuschnigg, Christian and Wilhelm Kohler (1999), Eastern Enlargement to the EU: Economic Costs and Benefits for the EU Present Member States: The Case of Austria, Study XIX/B1/9801 on Behalf of the European Commission, Brussels, available on www.economics.uni-linz.ac.at/members/kohler/eustud.htm.

[32] Keuschnigg, Christian and Wilhelm Kohler (2002), Eastern Enlargement of the EU: How Much Is It Worth For Austria?, Review of International Economics, 9, forthcoming.

[33] Keuschnigg, Christian, Mirela Keuschnigg and Wilhelm Kohler (2001), The German Perspective on Eastern EU Enlargement, The World Economy 24, 513-542

[34] Kohler, Wilhelm (2000a), Wer gewinnt, wer verliert durch die Osterweiterung der EU?, in: Lutz Hoffmann (ed.), Erweiterung der EU, Berlin: Duncker \& Humblot, 27-77.

[35] Kohler, Wilhelm (2000b), Die Osterweiterung der EU aus der Sicht bestehender Mitgliedsländer: Was lehrt uns dieTheorie der ökonomischen Integration?, Perspektiven der Wirtschaftspolitik 1, 115-142.

[36] Kohler, Wilhelm and Christian Keuschnigg (2000), An Incumbent Country View on Eastern Enlargemnt of the EU - Part I: A General Treatment, Empirica, 27, 325-351.

[37] Kohler, Wilhelm and Christian Keuschnigg (2001), An Incumbent Country View on Eastern Enlargemnt of the EU - Part II: The Case of Austria, Empirica, 28, 159-185.

[38] Lang, Derek, Theodore Palivos and Ping Wang (1995), Learning, Matching and Growth, Review of Economic Studies 62, 115-129.

[39] Matusz, Steven (1996), International Trade, the Division of Labour, and Unemployment, International Economic Review 37, 71-84.

[40] Merz, Monika (1999), Heterogeneous job-matches and the cyclical behaviour of labour turnover, Journal of Monetary Economics 43, 91-124.

[41] Mezzetti, Claudio and Elias Dinopoulos (1991), Domestic Unionization and Import Competition, Journal of International Economics 31, 70-100.

[42] Mortensen, D.T. and C.A. Pissarides (1999), Job reallocation, employment fluctuations and unemployment, in: Taylor, J.B. and M. Woodford (eds), Handbook of Macroeconomics, vol. 1B, Amsterdam: North-Holland. 
[43] Mortensen, Dale T. and Christopher Pissarides (1994), Job Creation and Job Destruction in the Theory of Unemployment, Review of Economic Studies 61, 397-416.

[44] Pissarides, Christopher A. (1990), Equilibrium Unemployment Theory, Oxford: Basil Blackwell.

[45] Rama, Martin (1997), Labour Market Institutions and the Second-Best Tariff, Scandinavian Journal of Economics 99, 299-314.

[46] Rama, Martin and Guido Tabellini (1998), Lobbying by Capital and Labour Over Trade and Labour Market Policies, European Economic Review 42, 1295-1316.

[47] Razin, Assaf and Efraim Sadka (1992), International Migration and International Trade, NBER Working Paper No. 4230.

[48] Schmidt, Christoph M. (1999), Persistence and the German Unemployment Problem: Empirical Evidence on German Labour Market Flows, Discussion Paper No. 31, IZA, Bonn.

[49] Shi, S. and Q. Wen, (1997), Labour Market Search and Capital Accmulation: Some Analytical Results, Journal of Economic Dynamics and Control 21, 1747-1776.

[50] Shi, S. and Q. Wen (1999), Labour Market Search and the Dynamic Effects of Taxes and Subsidies, Journal of Monetary Economics 43, 457-495.

[51] Sinn, H.-W., et al.(2001), EU-Erweiterung und Arbeitskräftemigration. Wege zu einer schrittweisen Annäherung der Arbeitsmärkte, ifo Beiträge zur Wirtschaftsforschung 2, München.

[52] Sinn, H.-W. \& M. Werding (2001), Immigration Following EU Eastern Enlargement, CESifo Forum, 2, 40-47. 
Table 1: Eastern Enlargement: Policy Decomposition

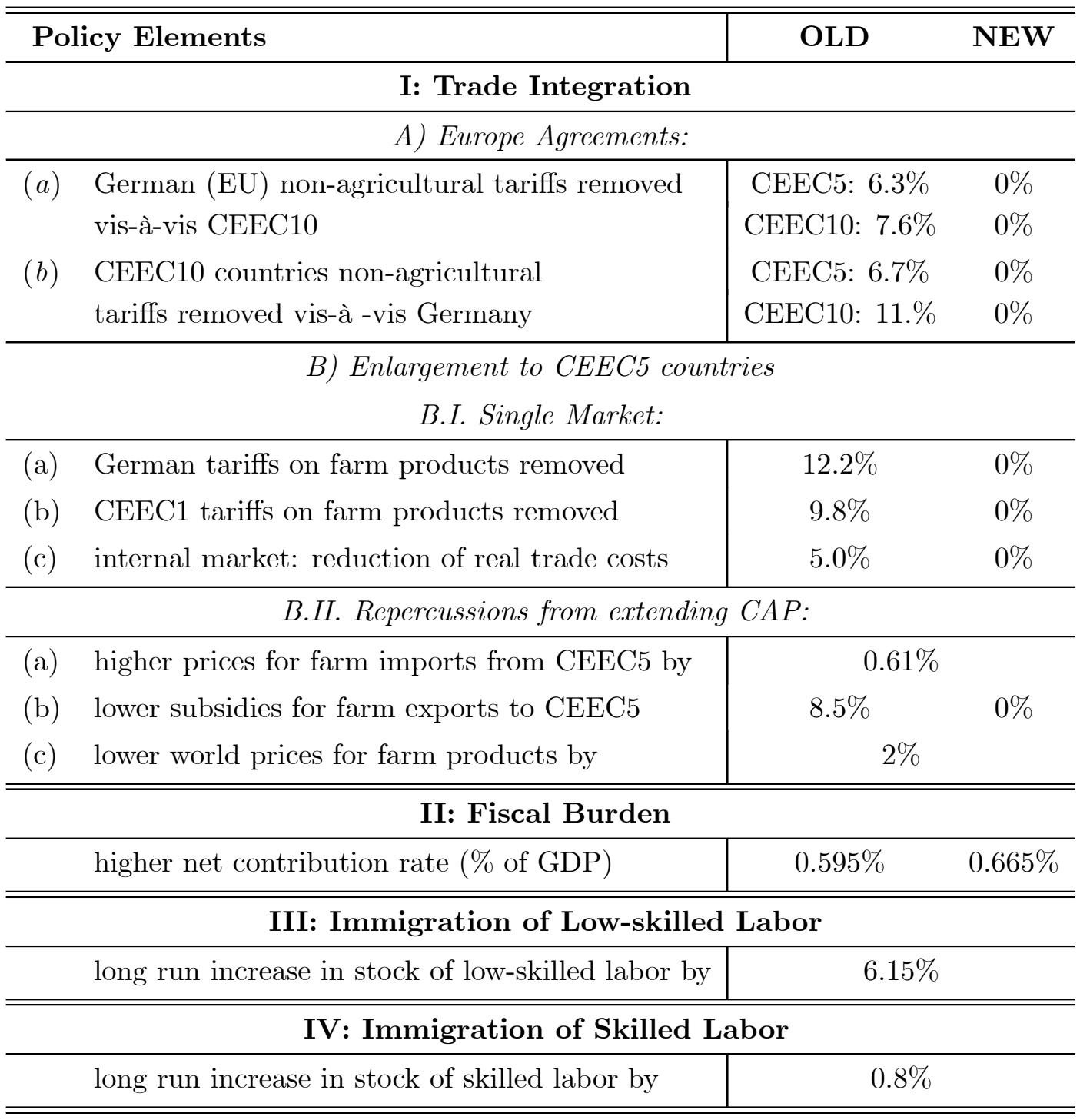


Table 2: Long-Run Effects on the German Economy

\begin{tabular}{ll|rrr|rrr}
\hline \multicolumn{2}{l|}{ Variables, changes in pc. $^{*}$} & Trade & Fiscal & Enl & Low & High & Migr** \\
\hline$P$ & consumer price index & -0.267 & -0.033 & -0.310 & -0.069 & -0.146 & -0.214 \\
$P^{I}$ & investment price index & -0.256 & -0.042 & -0.164 & -0.115 & -0.148 & -0.262 \\
$\bar{p}$ & dom. producer prices & 0.047 & -0.042 & 0.036 & 0.049 & -0.023 & 0.027 \\
$\bar{p}^{E}$ & terms of trade w.CEECs & 7.113 & -0.043 & 7.131 & -0.091 & -0.070 & -0.161 \\
$E^{E}$ & exports to CEECs & 57.350 & 0.188 & 57.392 & 1.043 & 0.806 & 1.861 \\
$E$ & total exports & 4.122 & 0.185 & 4.015 & 0.915 & 0.781 & 1.706 \\
$U^{s}$ & skilled unempl.rate, 6\%* & 5.944 & 6.001 & 5.935 & 5.912 & 5.977 & 5.890 \\
$U^{u}$ & unsk.unempl.rate, 10\%* & 9.937 & 10.000 & 9.903 & 10.544 & 9.879 & 10.402 \\
$U$ & av.unempl.rate, 6.668 \%* & 6.611 & 6.669 & 6.598 & 6.726 & 6.625 & 6.677 \\
$K$ & $\sum_{j}$ capital stocks & 0.524 & -0.019 & 0.630 & 1.330 & 1.164 & 2.513 \\
$\bar{n}$ & number of firms & 0.581 & 0.003 & 0.666 & 1.192 & 1.057 & 2.267 \\
$Y$ & gross domestic production & 0.402 & -0.058 & 0.376 & 0.988 & 0.826 & 1.824 \\
$w^{s}$ & wage rate, skilled & 0.522 & -0.049 & 0.602 & 1.174 & 0.171 & 1.353 \\
$w^{u}$ & wage rate, unskilled & 0.286 & -0.035 & 0.545 & -4.251 & 0.921 & -3.389 \\
$z$ & government transfers & 1.167 & -0.370 & 0.516 & 2.358 & 2.090 & 4.486 \\
$\omega$ & average disposable income & 0.796 & -0.201 & 0.536 & 1.771 & 1.511 & 3.308 \\
$C$ & average consumption & 1.065 & -0.169 & 0.847 & 1.842 & 1.660 & 3.531 \\
$E V$ & aggr.welfare, \% of GDP & 0.554 & -0.091 & 0.450 & 0.357 & 0.335 & 0.692 \\
\hline
\end{tabular}

Notes: Trade: Trade and CAP. Fiscal: Fiscal Cost. Enl: EU Enlargement. Low: Immigration of low-skilled. High: Immigration of high-skilled. Migr: Total Immigration. A bar (e.g. $\bar{p}$ ) denotes weighted averages of sectoral values. $\left.{ }^{*}\right)$ Labor market variables in absolute terms, initial values starred. ${ }^{* *}$ ) Welfare change relates to flow scenario while $E V=0.948$ for the stock scenario. 
Table 3: Alternative Fiscal Policy Assumptions

\begin{tabular}{ll|rrrr|r}
\hline \multicolumn{2}{c|}{ Variables, changes in pc. $^{*}$} & Enl & Index & $\operatorname{Ind} B^{U}$ & E/Tax & M/Tax \\
\hline$P$ & consumer price index & -0.310 & -0.299 & -0.305 & -0.323 & -0.276 \\
$P^{I}$ & investment price index & -0.164 & -0.152 & -0.152 & -0.178 & -0.331 \\
$\bar{p}$ & dom. producer prices & 0.036 & 0.038 & 0.035 & 0.034 & 0.013 \\
$\bar{p}^{E}$ & terms of trade w.CEECs & 7.131 & 7.138 & 7.138 & 7.122 & -0.203 \\
$E^{E}$ & exports to CEECs & 57.392 & 57.280 & 57.289 & 57.517 & 2.275 \\
$E$ & total exports & 4.015 & 3.945 & 3.951 & 4.095 & 2.100 \\
$U^{s}$ & skilled unempl.rate, 6 \%* & 5.935 & 6.000 & 6.016 & 5.861 & 5.544 \\
$U^{u}$ & unsk.unempl.rate, 10\%* & 9.903 & 10.000 & 10.028 & 9.790 & 9.770 \\
$U$ & av.unempl.rate, 6.668 \%* & 6.598 & 6.668 & 6.686 & 6.518 & 6.281 \\
$K$ & $\sum_{j}$ capital stocks & 0.630 & 0.540 & 0.554 & 0.733 & 3.019 \\
$\bar{n}$ & number of firms & 0.666 & 0.583 & 0.598 & 0.759 & 2.730 \\
$Y$ & gross domestic product & 0.376 & 0.313 & 0.323 & 0.448 & 2.173 \\
$w^{s}$ & wage rate, skilled & 0.602 & 0.594 & 0.632 & 0.612 & 1.410 \\
$w^{u}$ & wage rate, unskilled & 0.545 & 0.579 & 0.638 & 0.503 & -3.685 \\
$z$ & government transfers & 0.516 & 0.238 & 0.462 & -0.323 & -0.276 \\
$\omega$ & average dispos.income & 0.536 & 0.422 & 0.442 & 0.667 & 3.942 \\
$C$ & average consumption & 0.847 & 0.723 & 0.749 & 0.988 & 4.210 \\
$E V$ & aggr.welfare, \% of GDP & 0.450 & 0.384 & 0.395 & 0.519 & 0.693 \\
\hline & & & & & &
\end{tabular}

Notes: Enl: Real $B^{U}$ and $B^{L}$ constant. Index: $B^{U}$ and $B^{L}$ both indexed. $\operatorname{Ind} B^{U}: B^{U}$ indexed, real $B^{L}$ constant. E/Tax: Real $B^{U}, B^{L}$ and $z$ constant, wage tax endogenous. M/Tax: Total immigration, wage tax cut. A bar (e.g. $\bar{p}$ ) denotes weighted averages of sectoral values. $\left.{ }^{*}\right)$ Labor market variables in absolute terms, initial values starred. 
Table 4: Enlargement Scenario for EU15 Countries Overall Welfare Effect in \% of GDP

\begin{tabular}{l|r|r|r|r|r}
\hline & \multicolumn{1}{|c|}{$\begin{array}{c}\text { Trade } \\
\text { shares }\end{array}$} & \multicolumn{1}{c|}{$\begin{array}{c}\text { Fiscal } \\
\text { burden }\end{array}$} & \multicolumn{2}{|c|}{ Immigration } & \multicolumn{1}{c}{ Uelfare } \\
unskilled & \multicolumn{1}{c}{ skilled } & \multicolumn{1}{c}{ effect } \\
\hline Austria & 0.662 & 0.071 & 10.526 & 1.444 & 2.017 \\
Belgium (\#) & 0.230 & 0.225 & 1.419 & 0.144 & 0.166 \\
Denmark & 0.276 & 0.070 & 1.481 & 0.182 & 0.452 \\
Finland & 0.454 & 0.135 & 2.543 & 0.268 & 0.711 \\
France & 0.103 & 0.076 & 0.390 & 0.049 & 0.086 \\
Germany & 0.397 & 0.070 & 6.152 & 0.840 & 1.154 \\
Greece & 0.084 & 0.756 & 1.858 & 0.274 & -0.655 \\
Ireland & 0.167 & 0.684 & 0.052 & 0.007 & -0.657 \\
Italy & 0.187 & 0.100 & 0.609 & 0.089 & 0.201 \\
Luxembourg (\#) & 0.230 & 0.189 & 2.121 & 0.215 & 0.282 \\
Netherlands & 0.271 & 0.072 & 0.682 & 0.079 & 0.355 \\
Protugal & 0.032 & 1.025 & 0.072 & 0.010 & -1.289 \\
Spain & 0.057 & 0.409 & 0.312 & 0.037 & -0.423 \\
Sweden & 0.235 & 0.055 & 3.217 & 0.349 & 0.581 \\
UK & 0.090 & 0.068 & 0.689 & 0.077 & 0.107 \\
\hline Elasticity & 1.394 & -1.309 & 0.058 & 0.399 & \\
\hline
\end{tabular}

Legend:

Elasticity: Elasticity pertaining to the various enlargement "shocks" calculated from the German model; see text.

Trade shares: Country-specific measures of the size of the "shock" from commodity market integration (corresponding to scenario I in table 1, and column 1 in table 2); see text for more details.

Fiscal burden: Estimates of the cost of enlargement from the EU-budget in percent of GDP (corresponding to scenatio II in table 1, and column 2 of table 2).

(\#) Estimates from the scenario of increasing own resources. In all other cases estimates from the scenario of reducing structural funds are used.

Immigration: Cumulative inflows of skilled and unskilled workers, respectively, in percent of initial stocks (corresponding to scenarios III and IV of table 1, and columns 4 and 5 of table 2); see appendix A.8 for more details.

Welfare effect: Annual welfare gain in percent of GDP, calculated as sums of the elasticities multiplied the "shocks". 


\section{Figure 1: A "snapshot-view" of European Union Enlargements}

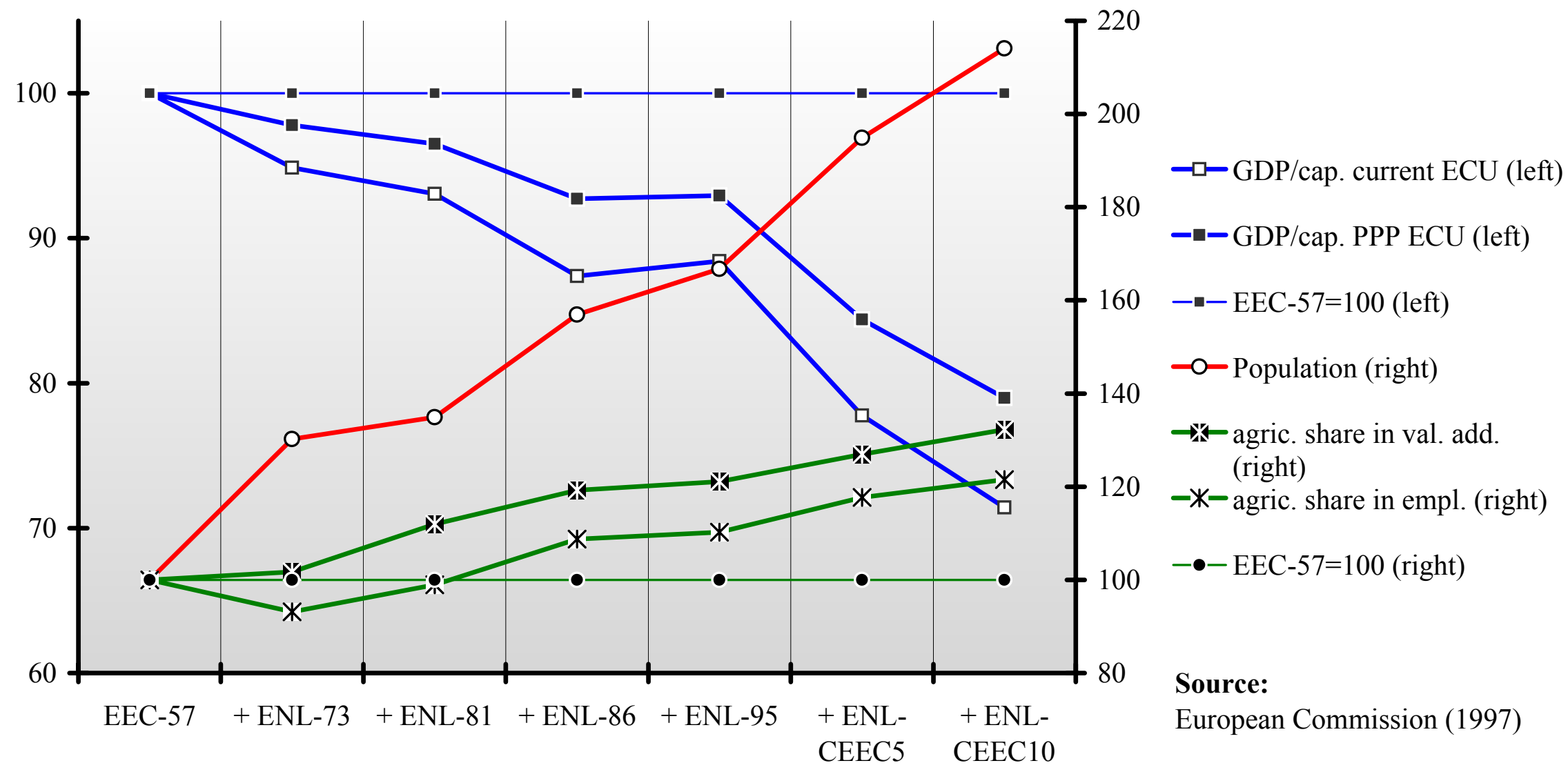

EEC-57: Belgium, France, Germany, Italy Luxembourg, Netherlands

ENL-73: Denmark, Ireland, United Kingdom

ENL-81: Greece

ENL-86: Portugal, Spain

ENL-95: Austria, Finland, Sweden

ENL-CEEC5: Czech Republic, Estonia, Hungary, Poland, Slovenia

ENL-CEEC10: Bulgaria, Latvia, Lithuania, Romania, Slovak Republic 


\section{Figure 2: Trade shares and trade barriers for EU15 merchandize trade with CEEC10s}

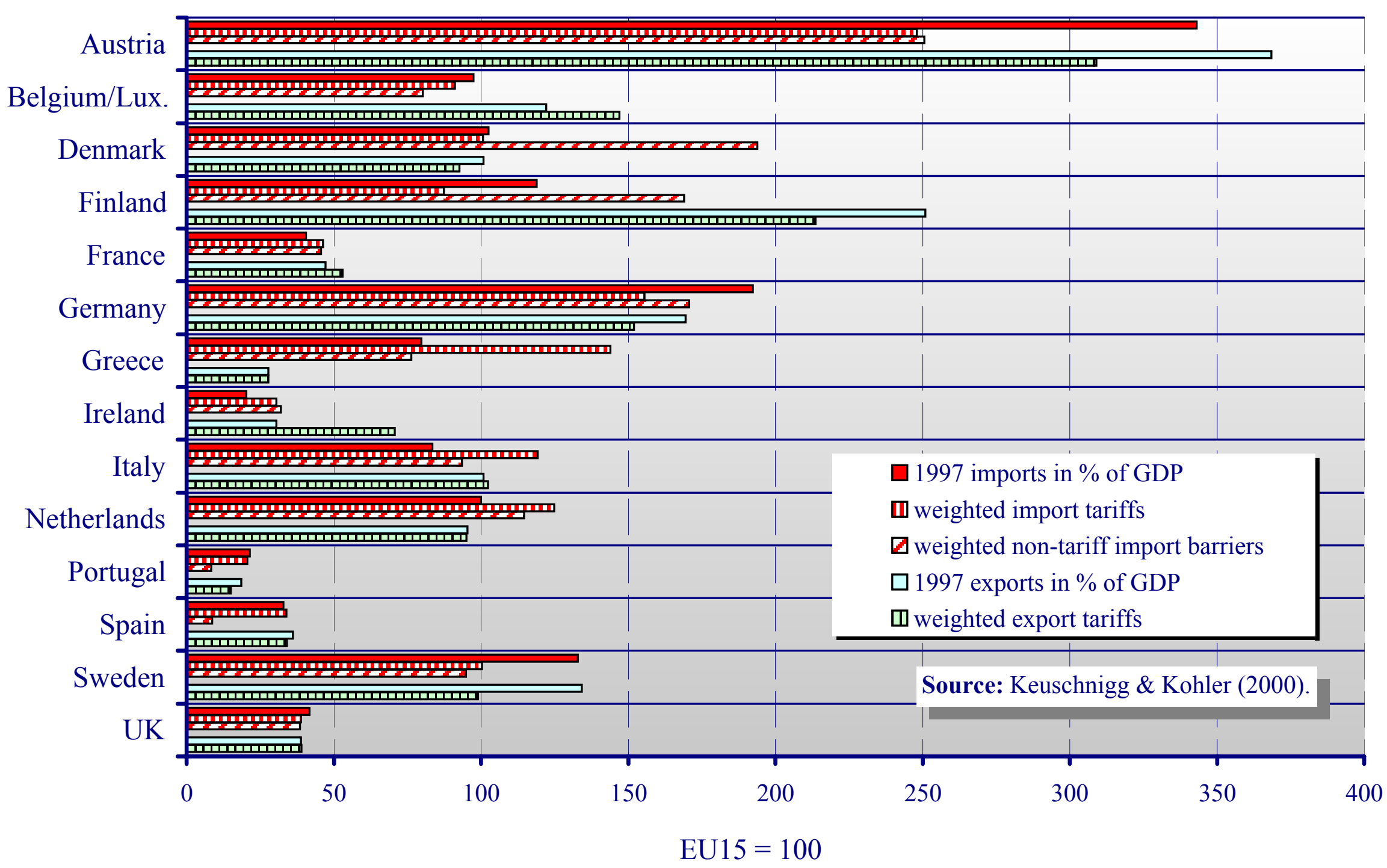


Figure 3: Stocks of residents and employees from CEEC10s in EU15 countries

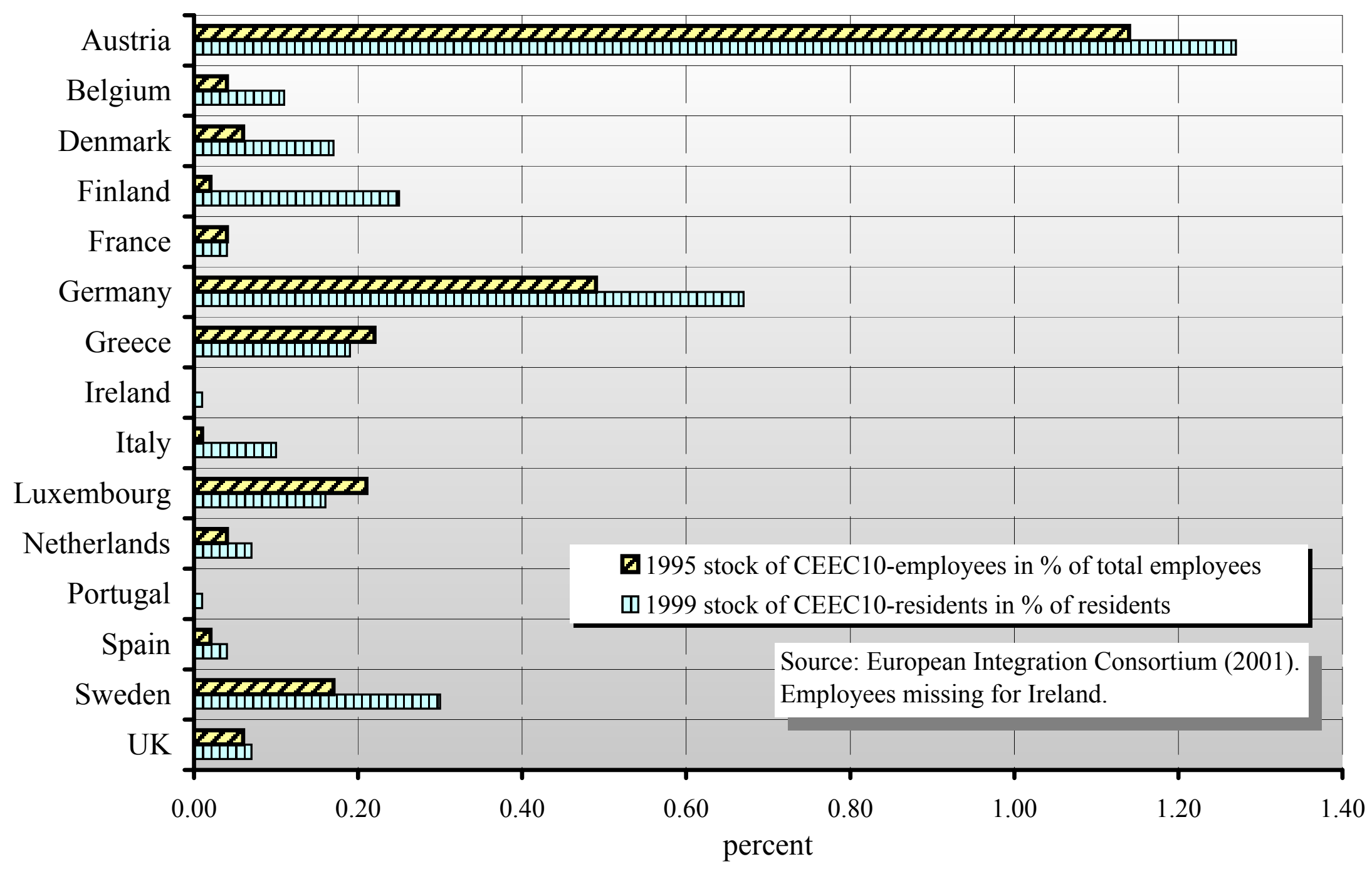


Figure 4.a: Immigration and Unemployment of Skilled Labor Simulation Results

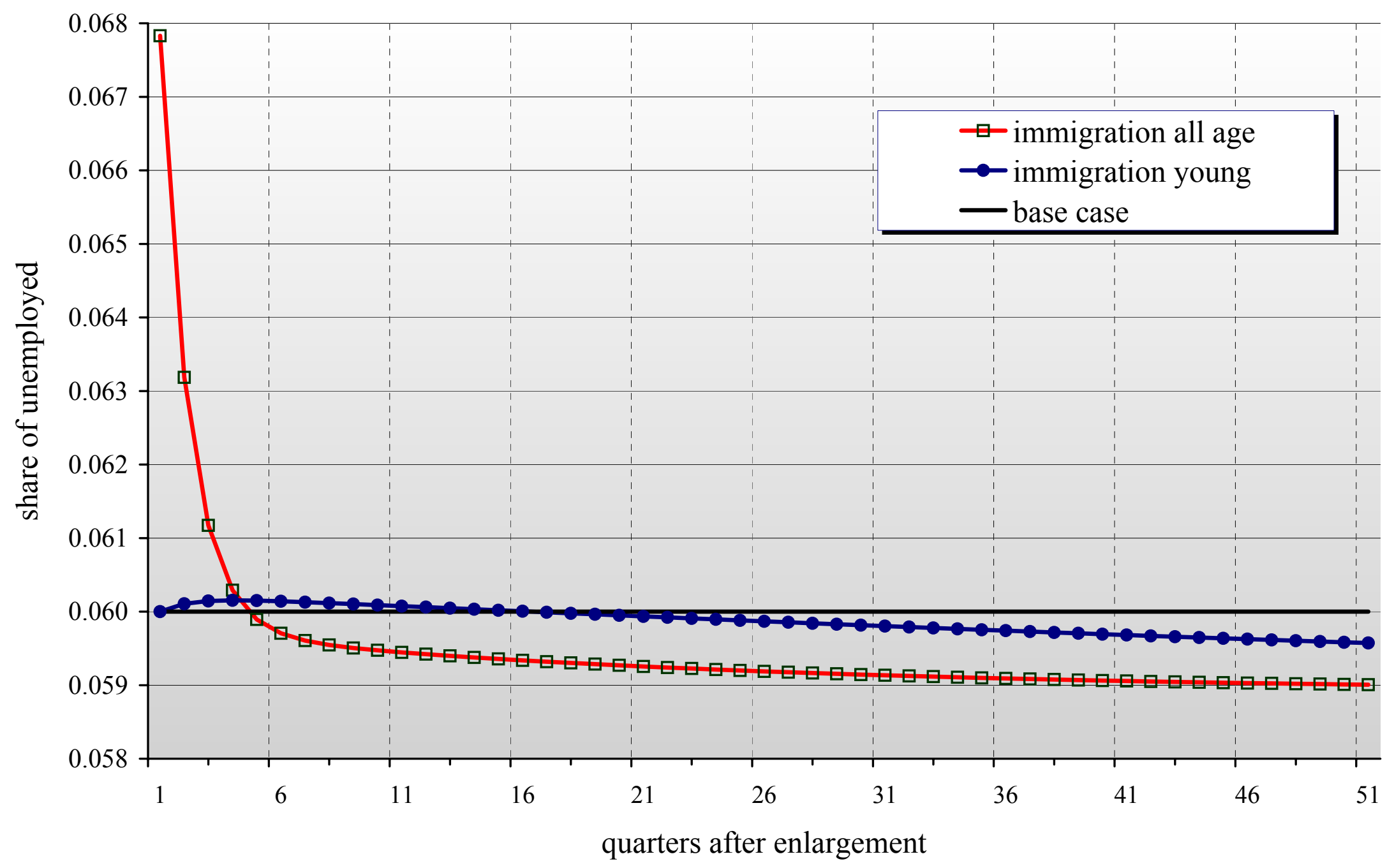


Figure 4.b: Immigration and Unemployment of Unskilled Labor Simulation Results

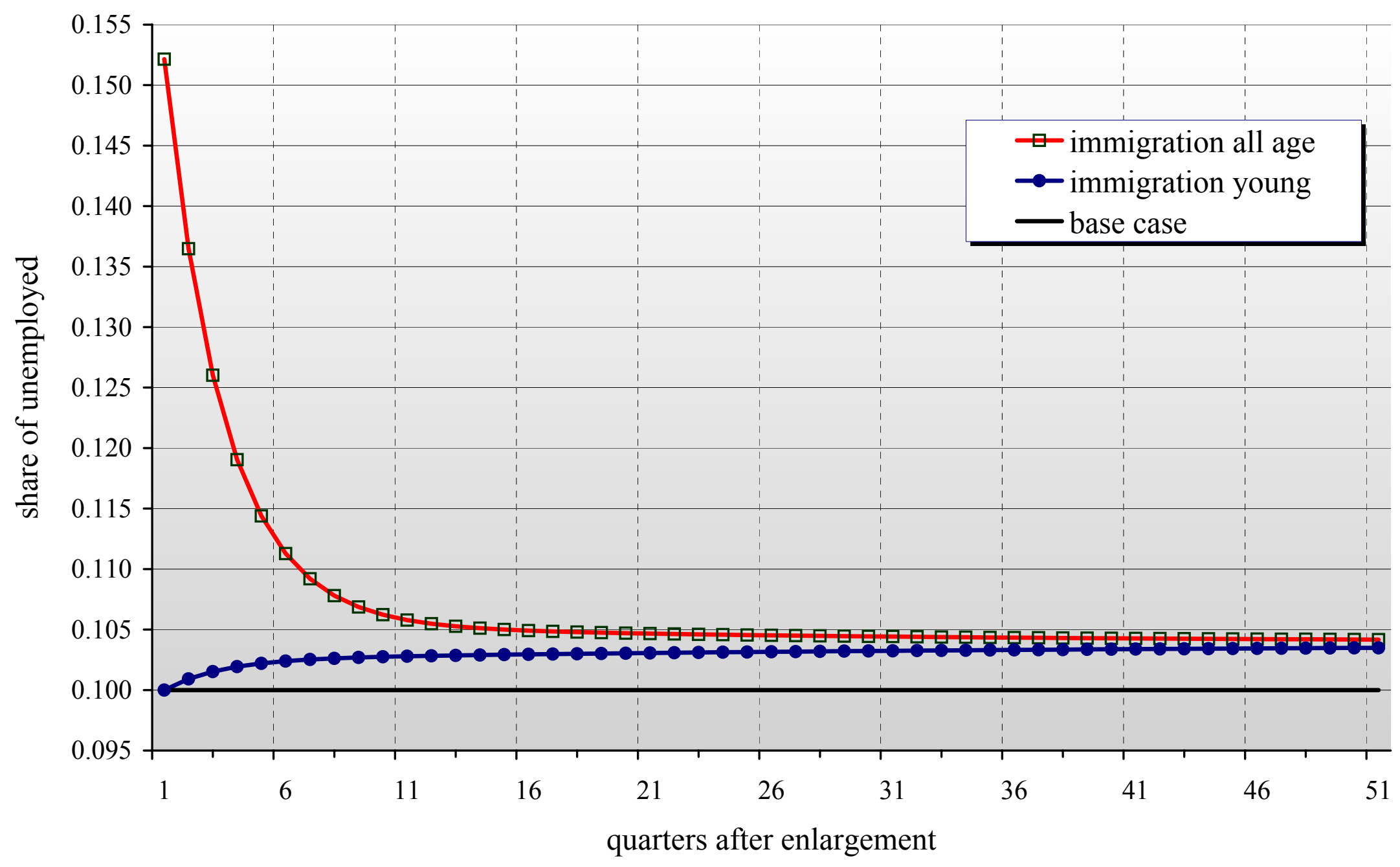


Fig. 5: Welfare effect of enlargement in EU15 countries, annual \% of GDP

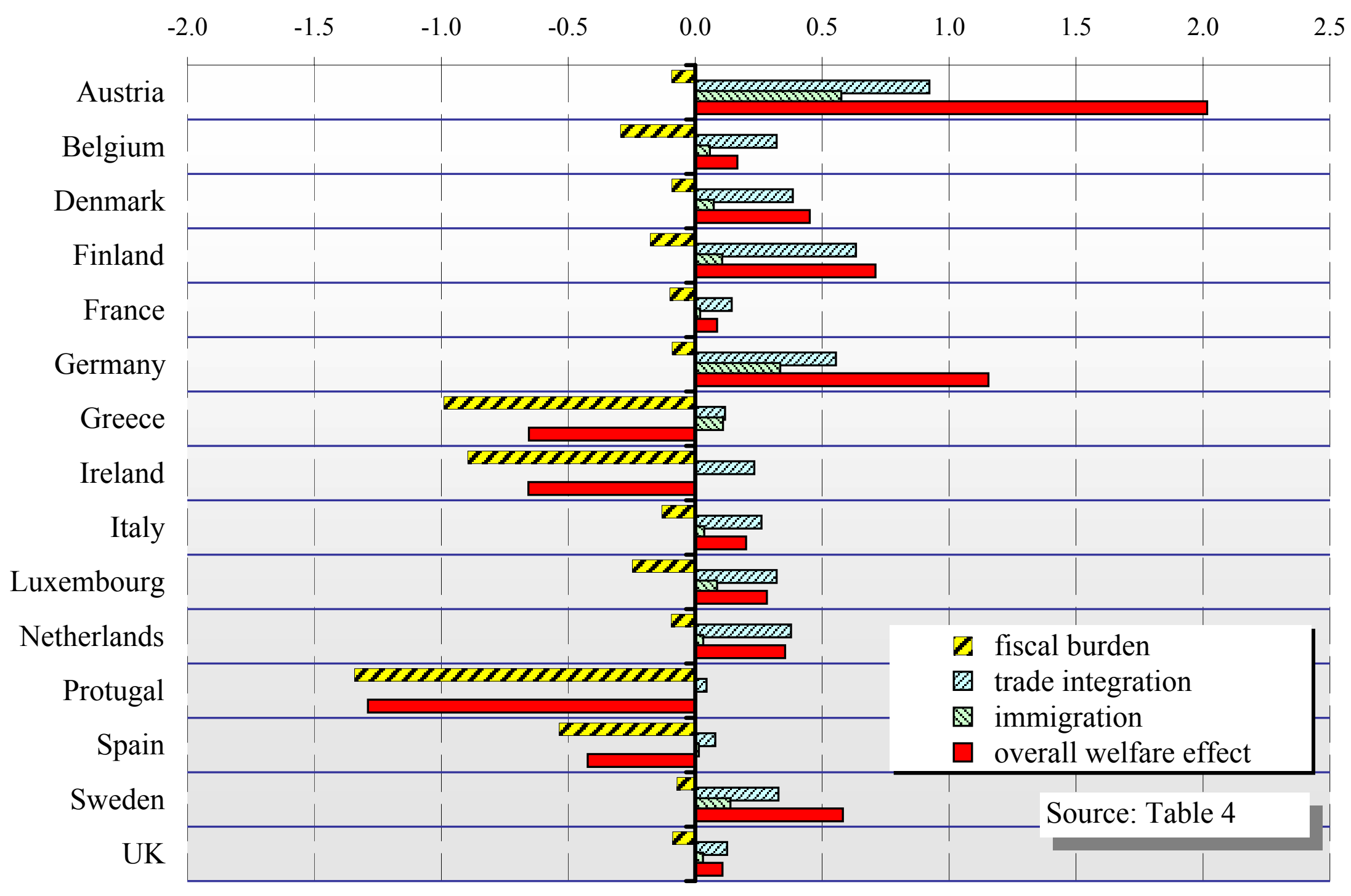

